\author{
Dr. sc. Bosiljka Britvić Vetma, docentica \\ Pravni fakultet Sveučilišta u Splitu
}

\title{
EUROPSKI POGLED NA UPRAVNOPRAVNU ZAŠTITU OKOLIŠA I URBANIZAM
}

\author{
UDK: 342. $a: 719(4)$ \\ Pregledni znanstveni rad \\ Primljeno: 20. 12. 2015.
}

\begin{abstract}
Ovladavanje urbanim razvojem postavlja zahtjeve u okviru integriranog i održivog postupka koji neophodno vodi do boljeg karakteriziranja procjene okoliša. U tom smislu pokušat ćemo ukazati koliko procjena okoliša snažno i izravno utječe na urbanističko planiranje, te na važnost Direktive 2001/42/EZ. U okviru ovog članka, ograničit ćemo se na područje primjene direktive, iako ćemo se posvetiti određenim temama koje su vezane za procjenu okoliša u užem smislu i praćenje okoliša koje nalaže direktiva. In fine, javne politike moraju se razvijati u inovativnom okviru, stremeći prema novom upravljanju, tj. sposobnosti da se odgovori na zahtjev ove međuovisnosti koja značajno opisuje ljudske odluke i djelovanja, bez obzira na razmatrano zemljopisno područje. Radi se o određivanju uvjeta interveniranja javnog djelovanja i o odgovornosti javnih vlasti s obzirom na životne uvjete i okoliš na planetu.
\end{abstract}

Ključne riječi: upravno djelovanje, urbanizam, zaštita okoliša, Direktiva 2001/42/EZ

\section{UVOD}

Procjena okoliša snažno i izravno utječe na urbanizam. U području strateških procjena okoliša instrumenti urbanističkog planiranja zauzimaju značajno mjesto. To se posebice odnosi na zadaću koju ti instrumenti imaju u distribuciji uporabe zemlje, u određivanju lokacije radova, koji imaju učinke na okoliš, i u određivanju dopuštenih pravila postupanja. Michel Prieur priznaje da procjena okoliša predstavlja „savez zdravog razuma i revolucije (...). Zdrav razum predstavlja primjenu starog načela bolje spriječiti nego liječiti, a to zahtijeva razmišljanje prije djelovanja“. Studija koja opravdava projekt pruža dokaze o razmišljanju kojem mogu doprinijeti sve zainteresirane strane, a posebno javnost. Mirna revolucija odnosi se na to da autori odluke moraju postupati transparentno. ${ }^{1}$

Procjena okoliša prvenstveno se primjenjivala na projekte aktivnosti, infrastrukturnih radova ili poslova čije je provođenje moglo izravno utjecati na okoliš. Deklaracija iz Ria tome je posvetila točku 17.: „Studija utjecaja na okoliš, kao nacionalni instrument, mora se provesti u slučaju da predviđene aktivnosti, koje mogu imati značajne štetne učinke na okoliš, ovise o odluci nadležnog nacionalnog tijela vlasti“. Danas, naročito, u odnosu na navedeno, zemlje članice

\footnotetext{
1 Prieur, Michel, Précis de droit de l'environnement, Paris, Dalloz, 2004., str. 78.
} 
Europske unije imaju normativne obveze. U okviru institucija Europske unije radi se o Direktivi od 27. lipnja 1985. o ,procjeni učinaka određenih javnih ili privatnih projekata na okoliš“ i i E Espoovoj konvenciji koja je sastavljena u okviru Gospodarskog povjerenstva Ujedinjenih naroda za Europu i potpisana 1991., a koja obuhvaća procjenu učinaka na okoliš preko državnih granica.

Za projekte koji se odnose na djelovanje ili radove, nacionalna ili regionalna zakonodavstva predviđaju postupke izdavanja suglasnosti ili odobrenja sukladno posebnim politikama o zaštiti okoliša u okviru kojih se predviđa studija utjecaja, a što se posebice odnosi na postrojenja koja uzrokuju onečišćenja. Međutim, na određeni broj ovih projekata ne primjenjuju se ove posebne politike već zakonodavstvo koje se odnosi na urbanizam iz dva razloga. Prvi se odnosi na to da se djelomično radi o djelovanju koje tradicionalno uređuje zakonodavstvo koje se odnosi na urbanizam, kao što su građenje i parceliranje, a kada je to potrebno, studija utjecaja na okoliš izrađuje se u okviru postupka izdavanja urbanističke suglasnosti. Drugi razlog odnosi se na pravo urbanizma koje se s vremenom razvilo u smjeru proširenja svog polja djelovanja, te služi kao baza za upravni nadzor različitih projekata koji utječu na korištenje zemljišta.

U tom smislu treba istaknuti važnost Direktive 2001/42/EZ. Francis Haumont ističe da je „u svakom slučaju sigurno da prostorno planiranje i urbanizam predstavljaju prvi sektor primjene direktive“ i navodi da je „simptomatično u tom smislu utvrditi da se primjeri iz praktičnog vodiča Komisije često odnose na urbanizam i prostorno planiranje“.2

\section{1. Pristup ekosustavu}

Brojni statistički podaci i znanstveni izvještaji pokazuju da ljudi moraju pokrenuti novi proces upravljanja planetom, kako bi pravedno zadovoljili potrebe ljudi koji danas žive i onih koji će nas nadživjeti, ali i kako bi učinili održivima okolišne uvjete života na planetu. Radi se o istovremenom razmatranju biosfere i biotopa, te je prema tome pristup ekosustavu neophodan. Mjerenje ekološkog otiska mora omogućiti da se odredi stvarni utjecaj čovjeka na okoliš. Ovaj pojam mogao bi odgovoriti na te uloge, u pogledu prava korištenje zemljišta i prostora, jer je istovremeno zanimljiv i lokalnom i globalnom pristupu.

\section{1. 1. Globalno određivanje}

U okviru neophodno interdisciplinarnog pristupa, radi se o utemeljenju uvjeta korištenja zemljišta i prostora na temelju objektivne ocjene utjecaja ljudskih postrojenja. S tog gledišta, ekološki otisak omogućuje mjerenje ljudskog utjecaja na ekosustave i planet u pogledu svog biološki produktivnog kapaciteta. Ekološki otisak varira ovisno o broju stanovnika, načinu potrošnje i o učinkovitosti u korištenju resursa. Mjeri se u hektarima koji su potrebni za proizvodnju hrane

2 Ibid. 
(npr. obrađeno zemljište, pašnjaci, oceani), ali u pitkoj vodi, energiji, otpadu i kretanju.

Ako krenemo od te ocjene, ljudsko biće je 2001. godine za $21 \%$ premašilo biološki kapacitet zemlje, ali ovi prosjeci loše prikrivaju nejednakosti, jer, ako jedan Sjeveroamerikanac ,troši“ 9,7 ha i jedan Europljanin 4,97 ha (Francuz 5,3 ha), stanovnik nekih afričkih zemalja ili zemalja Južne Amerike „troši“ manje od 0,20 ha. Duboke razlike se sada javljaju u načinima potrošnje resursa i u utjecaju na ekosustave. Vodeći računa o demografskim promjenama, 2050. planet će imati 9 milijardi stanovnika, a da bi se zadovoljile potrebe u potrošnji tog stanovništva, to bi zahtijevalo kapacitet od 1,8 do 2,5 planeta Zemlje.

Svjetsko tijelo vlasti za zaštitu okoliša, koje neki zazivaju, trebalo bi odrediti „kapacitet ekološkog otiska svake ekološke regije, odnosno svake države “. ${ }^{3}$ Kao za stakleničke plinove, moguće je procijeniti, prema stanovništvu i načinu potrošnje, doprinos svakog područja i njihove granice. Ne radi se o tome da treba obustaviti svaki razvoj, već se radi o pokretanju proizvodnih i potrošačkih politika kao i prilagođenog korištenja zemljišta i prostora, kao i o provođenju javnih politika koje će generirati ekološki razvoj, u smislu konferencije iz Stocholma.

U savršenom svijetu, postoji optimalni kapacitet zemlje koji može podnijeti učinke ljudskih aktivnosti i postrojenja. Prema tome, mogu se razviti dva komplementarna pristupa. Prvi bi bio globalni kojeg bi utvrdile različite međunarodne organizacije (Program UN-a za razvoj, Konferencija Ujedinjenih naroda o ljudskom okolišu, UNESCO, Fond ujedinjenih naroda za stanovništvo, Svjetska zdravstvena organizacija, Food and Agriculture Organization (FAO)) i skupine stručnih znanstvenika, kao što je IPCC, koji bi pridonijeli određivanju, a to pretpostavlja da se međunarodno pravo razvije s institucionalnog i s operativnog stajališta kako bi se to moglo provesti. Drugi pristup bio bi komplementaran jer bi bio na regionalnoj razini (npr. kontinentalni ili međudržavni clusteri kao što su Europska unija, Mercosur) koji bi omogućio da se precizira utjecaj teritorijalnih praksi, navodeći na taj način doprinos svakog clustera razvoju ekosfere, zatim određivanje potreba koordiniranih politika urbanog razvoja.

Učinkovitost jednog takvog pristupa pretpostavlja političku dinamiku i razvoj prava kojeg činjenice sve više zahtijevaju uz uvjet hitnosti, bilo da se radi o izmjeni prava trgovine koji karakterizira utjecaj na okoliš zbog razmjena bez stvarnog ograničenja ili o nastanku prava okoliša koji bi bio u stanju promijeniti ljudske odluke i aktivnosti.

\section{1. 2. Lokalna identifikacija}

Ako se nalaže globalni pristup, tada je lokalni pristup neizbježan. On prvenstveno omogućuje stvarni opis urbanog faktora, tj. praktičnu promjenu urbanog razvoja na određenom zemljopisnom području. Statistički pristupi 2008.

Vidi Lebreton, Jean-Pierre, L'évaluation envitonnementale et le droit de l'urbanisme, RFDA, Paris, 
otkrivaju nam identifikaciju ovog urbanog faktora kroz skup ključnih pojmova: urbano područje, urbani cluster, grad, urbana jedinica, aglomeracija, grad-središte, predgrađe, ruralno područje, rurbanizacija. Pravo urbanizma karakterizira ovaj urbani razvoj s institucionalnog stajališta (općina, skupina općina itd.), sa stajališta instrumenata za planiranje (općinske karte, lokalni urbanistički planovi (PLU), sheme područne koherentnosti (SCOT), direktiva za područno planiranje (DTA), uz pomoć zoniranja (urbanog, kojeg treba urbanizirati, poljoprivredno, prirodno i u šumama), ali i kroz pojmove kao što su urbana obnova, planiranje, ulaz u grad itd. Svaki element karakterizira urbani faktor s obzirom na njegov odnos na zemljopisno područje, a osim okolišnog pristupa, integrirani postupak nalaže da se razmotre socijalni i gospodarski aspekti.

To mogu biti lokalni urbanistički dokumenti u strateškom smislu. Prema tome, na toj bi razini bilo prigodno izmjeriti ekološki utjecaj urbanog ,štiha“ i njegovih promjena. Ekonomisti su kadri predložiti metode za stratešku procjenu, neoklasičnu za jedne, koja se temelji na stanju troškovi/prednosti, a s više kriterija za druge, nadopunjujući je s participativnim postupkom, što za rezultat daje pristup kojim se donosi odluka. Zahtjevi koji se odnose na relevantnost i koherentnost temelj su za osnaživanje zabrinutosti za okolišs. Pravo urbanizma može uključiti ovu procjenu. Ako se uskladi sa studijom utjecaja za neke projekte i ako se prezentacijska izvješća urbanističkih dokumenata jasnije referiraju na okolišna pitanja, tada se ekološki utjecaj urbanog razvoja neće procjenjivati kao takav. Prema tome, za pravnike se radi o određivanju uvjeta koji omogućuju procjenu ekološkog otiska plana ili programa, odnosno projekta. Radi se o uvođenju prave metode koja uključuje:

- podatke koji omogućuju da se lokalno područje upiše u područje koje nadilazi lokalnu razinu, uz simultano uzimanje u obzir brige za okoliš, socijalne i gospodarske zabrinutosti kako bi postupak bio „održiv“;

- analizu iz neposredne blizine koja omogućuje uspostavu odnosa između urbanog razvoja u pogledu lokalnih prostora, u okviru istog postupka.

Razmatrajući ova dva elementa, mogao bi se pojaviti lokalni doprinos klimatskim promjenama, onečišćenju zraka, korištenju vode, sanaciji, upravljanju otpadom (opasnim i ostalim), ali i s obzirom na javne službe, stanovanje, socijalne stanove, školovanje, zdravstvo itd., na razini uključivanja okoliša i društvenih razmatranja u gospodarsku aktivnost. Mjerenje ekološkog otiska tako se nalazi na dvije važne razine utjecaja ljudskog djelovanja, osobito lokalnog, ali i neophodno globalnog. Jedan od izazova s kojima se suočavamo jest i uključivanje ovog načina procjene u pravo urbanizma koje je često lokalizirano i ograničeno na državno područje dok su ulozi i regionalni i globalni. Prema tome, radi se o provođenju načina djelovanja ove procjene koja će ispunjavati te zahtjeve. Dakle, nameće se usporedni pristup. 


\section{1. 3. Usporedna procjena}

Procjena se ne može izvršiti bez istovremenog interdisciplinarnog i prospektivnog pristupa, posebice s obzirom na složenost koja proizlazi iz različitih ekoloških sustava koji određuju ravnotežu zemljopisnih područja gdje se izrađuju planovi, programi i projekti. Procjena nalaže ex ante analizu, analizu tijekom upravljanja sa stvarnim praćenjem i ex-post analizu. Budući da je pravo urbanizma pravo ,integrator“, referentni kriteriji za procjenu moraju uzeti u obzir elemente koji ga opisuju. U tom kontekstu, neophodnim se čini odrediti ciljeve koji će pridonijeti preciziranju metode koja utemeljuje postupak, ali i načine djelovanja ove procjene.

Do procjene ne može doći bez zajedničkih alata. Prema tome, prava procjena treba se temeljiti na zajedničkoj metodi koja omogućuje izmjeru utjecaja urbanizacije na cijelo zemljopisno područje. Trenutačna procjena ne temelji se na pravoj metodi već proizlazi iz različitih praksi, a sadržaj joj je pomalo problematičan. Ciljevi u praksi također nisu precizno određeni. Radi se o razjašnjavanju traženih ciljeva, a zatim o određivanju načina djelovanja.

S obzirom na ciljeve, procjena okoliša mora omogućiti sljedeće:

- pridonijeti poboljšanju znanja na određenom zemljopisnom području i smjestiti ih u njegov lokalni i globalni kontekst;

- za donositelje odluka ex-ante odrediti stanje koje doprinosi poboljšanju postupka donošenja javnih odluka, koje se odnose na korištenje zemljišta na određenom zemljopisnom području, što uključuje mjerenje postojećeg ekološkog otiska kao i globalne učinke svih lokalnih odluka;

- uz poznavanje tematike, odrediti ljudski odnos prema određenom zemljopisnom području, zatim usmjeriti odluke koje se odnose na reguliranje ovog problema, ali i zaštite, iz kojih proizlazi djelovanje zabrana ili uvjetovanih briga, određivanje načina zaštite resursa, bioraznolikosti, krajobraza kao prirodne ili kulturne baštine, što može dovesti do neutraliziranja razvoja ili ga strogo uvjetovati;

- pridonijeti organizaciji praćenja okoliša u pogledu korištenja zemljišta, uzimajući u obzir najveću osjetljivost određenih zemljopisnih područja;

- pridonijeti praćenju učinaka ljudskog djelovanja na okoliš i zemljopisna područja, ex-post ocjena koja treba omogućiti prilagodbu odluka. ${ }^{4}$

$\mathrm{K}$ tome, osim okolišnog pristupa, perspektiva održivog razvoja nalaže da se uključe socijalni zahtjevi. Također, socijalnu različitost kao sastavni dio načela koji se odnose na planiranje treba prenijeti u procjenu. Među elementima koji ga opisuju postoji procjena usklađenosti strategije i akcijskog plana s pet ciljeva održivog razvoja koji slijede: klimatske promjene i atmosfera; bioraznolikost, sredine i resursi; rast; kohezija, solidarnost i ravnoteže; odgovorna proizvodnja i potrošnja. S obzirom na cilj koji se želi postići, mjerenje ekološkog otiska

4 Ibid. 
izgleda kao jedan od načina koji pridonose određivanju „održive urbanizacije““5 što uključuje i određivanje načina djelovanja.

\section{1. 4. Načini djelovanja}

Mjerenje ekološkog otiska predstavlja istinsku kulturnu promjenu odnosa ljudi prema zemljopisnom području.

Koji su to ulozi svojstveni ekološkom otisku? Prije svega, radi se o pokretanju postupka procjene koja omogućuje ocjenjivanje utjecaja čovječanstva na lokalnom zemljopisnom području, ali i s obzirom na njegove globalne utjecaje. U praksi, dvije razine ne mogu se odvojiti, što predstavlja izazov za javne urbane politike i pravo koje iz njih proizlazi.

Moguće je odrediti utjecaj načina potrošnje zemljišta koje posebice proizlazi iz urbanog razvoja, uključujući i individualne izbore. Ekološki se otisak na taj način pokazuje na lokalnoj i globalnoj razini. Budući da urbanistički dokumenti na određenom zemljopisnom području izražavaju perspektive postrojenja ljudi u njihovoj raznolikosti i određuju načine korištenja i potrošnje resursa, oni moraju omogućiti da se odredi doprinos zemljopisnog područja u globalnijem otisku.

Načini djelovanja trebaju dovesti do uključivanja novih praksi u pravo urbanizma. Pravo mora uzeti u obzir evaluacijske alate, a u tom smislu pokazatelji predstavljaju najrelevantniji trenutačni način koji može dati odgovore, premda još ne predstavljaju element važećih evaluacijskih postupaka i tehnika. Međutim, njihovo korištenje mora se temeljiti na skupu jamstava u okviru prilagođenog postupka.

a) S obzirom na pokazatelje. Oni omogućuju iskazivanje ciljeva koje treba ostvariti. Oni nastoje kvantificirati i pojednostaviti podatak. Referiranje na pokazatelje vodi do usporednog postupka, tj. do zajedničkih kriterija koje primjenjuju različita tijela zadužena za pitanja korištenja zemljišta, ali i različiti društveno-gospodarski akteri i javnost, bez obzira na mjesto djelovanja. Ako se referiramo na rješenja koja se primjenjuju na različitim razinama važeće prakse, možemo reći da svaka procjena ljudskog utjecaja na okoliš kao i ljudsko stanje podrazumijeva skup specifičnih kriterija. Kako bismo pomirili uloge koje predstavlja procjena, brojne institucije uvele su pokazatelje.

Moguće je povezati skup danas važećih pokazatelja:

- Prvo spomenimo one koje primjenjuju različite međunarodne institucije kao što su Fond Ujedinjenih naroda za stanovništvo, Centar Ujedinjenih naroda za ljudska naselja, program Ujedinjenih naroda za razvoj ili Svjetska zdravstvena organizacija. ${ }^{6}$ Ove institucije se referiraju na različite pokazatelje koji omogućuju određivanje utjecaja ljudskog djelovanja na zemljopisnu površinu: stanovništvo,

5 Francis, Haumont, Les charges d'urbanisme, Aménagement-Environnement, Louvain, 1994., str. 170-181.

6 Više o tome na http://www.mvep.hr/hr/vanjska-politika/multilateralni-odnosi/ujedinjeni-narodi$\% 28$ un $\% 29 /$ specijalizirane-agencije-ujedinjenih-naroda/ 
odgovarajuća površina zemljopisnog područja, stanovništvo po hektaru obradivog i obrađenog zemljišta, razina potrošnje, broj vozila, stanovništvo koje ima pristup vodi, stanovništvo koje raspolaže sustavom za pročišćenje otpadnih voda, stanovništvo bez stambenog prostora, stanovništvo u privremenom smještaju (slamovi i slično), životni vijek, stopa pothranjenosti, razina prikupljanja otpada, stopa demografskog rasta, promjena bioraznolikosti, stanje voda (kvantitativno, kvalitativno), onečišćenje zraka...

- Nadalje, važeći pokazatelji su i neke od NVO-a kao što je Worldwide Fund for Nature (WWF, Svjetska zaklada za prirodu) ${ }^{7}$ koja mjeri ekološki otisak, a temelji se na određivanju potrebnih površina, u hektarima, za proizvodnju hrane i vlakana koje konzumira čovjek, kako bi se zadovoljila njegova potrošnja energije i kako bi se pružio potreban prostor za infrastrukturu. To obuhvaća: obrađeno zemljište, pašnjake, šume, ribarska područja, energiju i izgrađena zemljišta. Ekološki otisak također određuje indeks živog planeta što je pokazatelj stanja prirodnih ekosustava, a proizlazi iz prosjeka tri indeksa: indeks populacije šumskih vrsta koje žive u šumskim ekosustavima, indeks slatke vode koji obuhvaća stanovništvo koje živi u ekosustavima jezera, rijeka, močvara i morski indeks koji određuje vrste koje se nalaze u morskim i obalnim ekosustavima.

- Na unutarnjem planu za IFEN ${ }^{8}$ moguće je ocijeniti održivi razvoj na temelju 45 velikih pokazatelja koji se odnose na urbano širenje. Nadalje, ovo tijelo je uvelo praćenje okolišnog utjecaja u odnosu na 10 ključnih pokazatelja za okoliš koji uključuje efekt staklenika, izdatke koji se odnose na zaštitu okoliša. Iskušane su i prakse ovladavanja urbanim širenjem. Provođenje lokalnih Agendi 21 ili određenih planova (npr. SAGE, sheme za planiranje i gospodarenje vodama) omogućili su nastanak tih pokazatelja. Radi se o uspostavljanju jedne vrste potke s pokazateljima koji se smatraju važnima, bez obzira na promatranu razinu zemljopisne površine. Za osjetljive ili posebne zemljopisne površine ovi temeljni pokazatelji nadopunjuju se dodatnim pokazateljima. Nakon što se jednom ovi pokazatelji potvrde, tada ih se uključuje u pravo urbanizma.

b) $\mathbf{S}$ obzirom na provođenje ove procjene. Izrada, izmjena ili revidiranje dokumenata za urbanističko planiranje, kao i provođenje projekata temelje se na pravilima i postupcima. Mjerenje ekološkog otiska određuje prilagođeni postupak u kombinaciji s jamstvima. Radi se o osnaživanju i razvoju ove procjene koja danas predstavlja jedan od elemenata iz prezentacijskog izvješća što ga izrađuju isti akteri kao i sami dokument, a koji se ne može jasno odvojiti od prikaza stanja, političkog projekta, kao i uvjeta korištenja zemljišta. Ekološki otisak ne može se odvojiti od životnih uvjeta stanovništva, a zahtijeva transverzalni pristup koji uključuje i socijalni aspekt.

\footnotetext{
Dodano pojašnjenje na http://croatia.panda.org/wwf/to_znae_inicijali_wwf/

8 Haumont, Francis, Droit européen de l'aménagement du territoire et de l'urbanisme, Bruylant, Paris, 2007.
} 
Ova bi procjena trebala prethoditi svakoj odluci o planiranju ili o projektu na određenom zemljopisnom području, a temelji se na funkcionalnim i materijalnim zahtjevima:

- S funkcionalnog stajališta i kako bi zajamčila načine djelovanja, ovu procjenu trebaju izraditi ovlašteni stručnjaci koji ne ovise o lokalnim ulozima. Ovi stručnjaci trebaju moći točno odrediti postojeći ekološki otisak i njegove promjene s obzirom na perspektivu urbanističkog razvoja (planiranje, program ili projekt), te postaviti uvjete teritorijalnog pristupa koji odgovaraju izazovima stvarne održivosti. Ovo djelovanje bi na taj način bilo neodvojivo od planiranja ili odluke koja se odnosi na projekt. Praćenje ove procjene moglo bi se odvijati bez predviđanja uloga vlasti ili lokalnih zemljišnih knjiga.

- S materijalnog stajališta, procjena ekološkog otiska treba se temeljiti na „zajedničkim“ kriterijima koji omogućuju razvijanje usporednog pristupa. Prema tome, takvo kakvo je prezentacijsko izvješće o dokumentu urbanističkog planiranja ili okolišni aspekt projekta mora se održati jer omogućuje određivanje stanja (demografskog, okolišnog, imovinskog, socijalnog, gospodarskog itd.), dok bi ekološki otisak prethodno omogućio izmjeru utjecaja skupine ljudi na zemljopisnom području i pokazao mogućnosti i ograničenja urbanističkog razvoja.

Ako se ne može izbjeći pitanje troškova koji nastaju na taj način, izvori financiranja mogu biti raznoliki. Europski programi i fondovi mogu pridonijeti olakšavanju provedbe. Najvažnije je moći izmjeriti i usporediti utjecaj razvoja korištenja zemljišta bez obzira na njihovu lokaciju i određujući njihov opseg s obzirom na regionalne i globalne uloge.

Temeljeći se na materijalnim jamstvima (nesporna metodologija i zajednički kriteriji), funkcionalni pristup (neovisnost procjenitelja) i jasno određeni postupak, mjerenje ekološkog otiska dobro ispunjava zahtjev za procjenu urbanog „,stiha“. Mjerenje bi također moglo predstavljati način sprečavanja urbanističkog širenja što je zagovarao zakon o okolišu „Grenelle“.

\section{PROCJENA OKOLIŠA I URBANISTIČKO PLANIRANJE}

\subsection{Općenito}

Uzimanje u obzir zabrinutosti za okoliš u urbanističkim dokumentima nije tako recentan cilj kao što nam se to može činiti. Još od 1972. tijekom prve Konferencije Ujedinjenih naroda o okolišu, koja se održala od 5. do 16. lipnja 1972. u Stocholmu, deklaracija od 13. lipnja 1972. o okolišu sadržavala je dvadeset pet načela od kojih trinaesto kaže sljedeće:

„Kako bi se racionaliziralo gospodarenje resursima i na taj način poboljšao okoliš, države bi trebale usvojiti integriranu i koordiniranu zamisao svog razvojnog planiranja, na način da njihov razvoj bude kompatibilan s potrebom da se zaštiti i poboljša okoliš u interesu njihovog stanovništva".

9 Drobenko, Bernard, Evaluation environnementale des documents d'urbanisme: entre enjeux et méthodes, RFDA, Paris, 2008. 
Upravo je to smisao članka 7. Svjetske povelje za prirodu koju je usvojila Glavna skupština Ujedinjenih naroda 28. listopada 1982. i gdje se navodi: „U planiranju i provedbi društveno-gospodarskih razvojnih aktivnosti, trebat se voditi računa o tome da očuvanje prirode bude sastavni dio tih aktivnosti“ “. ${ }^{10}$

Tijekom druge konferencije Ujedinjenih naroda o okolišu i razvoju koja se održala u Rio de Janeiru, deklaracija od 13. lipnja 1992. sastoji se od dvadeset sedam načela, a četvrto načelo glasi: „Da bi se postigao održivi razvoj, zaštita okoliša mora biti sastavni dio razvojnog procesa i ne može se izdvojeno razmatrati““. ${ }^{11}$

Ako ove dvije deklaracije i ova Povelja ne predstavljaju pravno obvezujuće tekstove, onda su, barem, značajno utjecale na sastavljače obvezujućih tekstova.

U Okvirnoj konvenciji o klimatskim promjenama od 9. svibnja 1992. ${ }^{12}$ također pronalazimo obvezu za strane ugovornice Konvencije koje moraju u svojim politikama i socijalnim, gospodarskim i okolišnim aktivnostima, a i u urbanističkom planiranju, voditi računa o utjecajima projekata na klimatske promjene. Sličan pristup pronalazimo u Konvenciji iz Ria o biološkoj raznolikosti, od 5. lipnja 1992., ${ }^{13}$ koja nalaže strankama obvezu uključivanja, u onoj mjeri u kojoj je to moguće, u očuvanje i održivosti korištenja biološke raznolikosti u relevantne sektorske i međusektorske planove i programe.

Nadalje, Konvencija iz Espoa od 25. veljače 1991. o procjeni utjecaja na okoliš, ${ }^{14}$ u kontekstu preko državnih granica, ohrabruje strane na primjenu načela iz Konvencije i to ne samo na projekte, već i na planove i programe. U tom smislu, tijekom sastanka u Sofiji 26. i 27. veljače 2001. odlučeno je da se pripremi pravno obvezujući protokol koji je usvojen u Kijevu 21. svibnja 2003., tj. Protokol Konvenciji iz Espoa koji se odnosi na stratešku procjenu okoliša. ${ }^{15}$ Do 1. kolovoza 2008. devet potpisnica ratificiralo je protokol čije stupanje na snagu zahtijeva šesnaest ratifikacija. ${ }^{16}$ Znamo da je trebalo pričekati usvajanje Jedinstvenog europskog akta od 7. kolovoza 1986. koji je stupio na snagu 1. srpnja 1987., da bi se na taj način izmijenjenim Rimskim ugovorom priznala formalna nadležnost europskih vlasti u području okoliša. Tom prilikom, bivši članak 130R, 2. stavak koji sadrži načela okolišne politike, glasio je: „Potrebe za zaštitom okoliša sastavni su dio drugih politika Zajednice“. Danas znamo da upravo članak 6. predstavlja temelj ovog načela ili ove integrativne klauzule: „Zahtjevi u pogledu zaštite okoliša moraju se uključiti u utvrđivanje i provedbu politika i aktivnosti Unije obuhvaćenih člankom 3., posebice s ciljem promicanja održivog razvoja“.

\footnotetext{
10 Ibid.

11 Ibid.

12 http://narodne-novine.nn.hr/clanci/medunarodni/328925.html

13 http://narodne-novine.nn.hr/clanci/medunarodni/1996_05_6_39.html

14 http://narodne-novine.nn.hr/clanci/medunarodni/328628.html

15 Ekonomska komisija za Europu.

16 Članak 24.
} 
Akcijski programi Zajednice za zaštitu okoliša od 1983. naglašavaju važnost aktivnosti zajednice u „uključivanju okolišne dimenzije u ostale politike“. ${ }^{17}$

Peti akcijski program u pogledu okoliša, usvojen 1993., nadopunjen 1998., afirmirao je važnost procjene učinaka koje planovi i programi mogu imati na okoliš. Upravo Direktiva 92/43/EEZ od 21. svibnja 1992. o očuvanju prirodnih staništa i divlje faune i flore (,habitat“) koji kroz svoj članak 6., stavak 3., nalaže odgovarajuću procjenu učinaka koje bi projekti, ali i planovi mogli imati na zaštićeno područje. Iako se ova odgovarajuća procjena očito usredotočuje na učinke planova na zaštićenu floru i faunu, ipak se radi o tome da su urbanistički planovi obvezatno podložni procjeni okoliša.

Također ćemo primijetiti da Europski sud za zaštitu ljudskih prava, usprkos nedostatku službenog priznanja u Konvenciji za zaštitu ljudskih prava i temeljnih sloboda i u dodatnim Protokolima o pravu na zaštitu zdravog okoliša, neizravno priznaje ovo pravo i posebice $u$ članku 8. koje štiti pravo na poštovanje privatnog i obiteljskog života i doma. Članak 8., stavak 2. ipak omogućuje uplitanje u ostvarivanje tog prava kada se radi o projektima od općeg interesa. ${ }^{18}$ Da bi se uvjerili da uplitanje poštuje načelo razmjernosti i vodi računa o pravima zaštićenima u skladu s člankom 8., stavkom 1., sud se, od predmeta Hatton, jasno usmjerava prema nalaganju postupovnih obveza u duhu Konvencije iz Aarhusa od 25. lipnja 1998. o pristupu informaciji, sudjelovanju javnosti u postupku odlučivanja i pristupu pravosuđu u pogledu okoliša. ${ }^{19}$ „Kada država obrađuje složena pitanja okolišne i gospodarske politike, postupak odlučivanja prije svega treba obuhvaćati provođenje odgovarajućih istraživanja i studija, kako bi se spriječilo i unaprijed procijenilo učinke aktivnosti koje mogu negativno utjecati na okoliš i prava pojedinaca i na taj način omogućiti uspostavljanje prave ravnoteže između različitih suprostavljenih interesa" ${ }^{20}$

Time se također nalaže procjena okoliša koja primjerice prethodi usvajanju urbanističkog plana koji bi mogao predstavljati uplitanje u pravo na kvalitetan okoliš.

\section{2. Posebnosti}

Primjena procjene okoliša na urbanističko planiranje opravdana je zbog potrebe da se obuhvate infrastrukturni projekti i projekti poslova koji ce biti predmet studije utjecaja kada to bude potrebno, čim se predvidi načelo njihove provedbe. Upravo u okviru plana stvara se odluka, često krucijalna u odvijanju postupka, nakon kojeg infrastrukturni radovi i poslovi postižu svoj cilj.

17 Ibid.

18 Haumont, Francis, Le droit fondamental á la protection de l'environnement dans la Convention de Sauvegarde des Droits de l'Homme et des Libertés Fonfamentales, Aménagement-Environnement, Paris, 2008., str. 9-55.

19 Izvješće Vijeća Europe od 27. lipnja 2003.

20 Europski sud za zaštitu ljudskih prava, 10. studenog 2004. Taskin i ostali protiv Turske; 28. ožujka 2006. Ockan i ostali protiv Turske, 2. studenog 2006. Giacomelli protiv Italije. 
Zanimljivo je primijetiti da su sve članice Europske unije prenijele Direktivu 2001/42/EZ o procjeni učinaka pojedinih planova i programa na okoliš. Također je zanimljivo za primijetiti da Švicarska nije propisala procjenu okoliša za svoje planove i da ta tema izaziva rasprave u Švicarskoj. Ova procjena je ipak ,ušla na kantonska vrata“ jer je Ženeva usvojila sustav koji se oslanja na Direktivu 2001/42. Međutim, vrata Konfederacije ostaju zatvorena jer ,instrument izaziva podjele“ ${ }^{21}$ Primjedbe protiv procjene planova ne zaustavljaju se na prednostima koje ona pruža u smislu transparentnosti i mogućnosti istraživanja alternativnih rješenja, koja, u biti, ističu da su instrumenti za planiranje već obvezni uključiti podatke o zaštiti okoliša, da je ,planiranje kao takvo koordinacijski instrument (...), a zaštita okoliša je transverzalna komponenta koju prostorno planiranje treba uključiti kada uređuje moguće korištenje zemljišta“".22 Tome pridodajemo da su instrumenti za urbanističko planiranje, koji su namijenjeni sažetom prikazivanju, uključeni u normativnu mrežu u kojoj moraju uzeti u obzir ili ugraditi izbore koji proizlaze iz planova i drugih pravnih propisa namijenjenih okolišu. Kroz ova dva usmjerenja, onog Europske unije i onog švicarskog, postavlja se pitanje o tome na koji način urbanistički dokumenti uzimaju okoliš u obzir i točnije, postavlja se pitanje o svrsishodnosti uvođenja posebnih zahtjeva za okoliš. U stvarnosti, postavljaju se dva pitanja. Prvo se tiče dodane vrijednosti zbog postupka koji se nadovezuje na postojeće mehanizme koji pridonose izvršenju istog cilja uz rizik povećanja troškova koji ne bi bio opravdan. Ovdje je teško nadići fazu metodičke sumnje, a odgovor ovisi o pravnoj procjeni nacionalnog sustava u kojem se nalazi strateška procjena okoliša. Drugo pitanje utječe na duboku prirodu urbanizma. Bit urbanističkih planova koji definiraju namjenu zemljišta da ispune funkciju sinteze koja ih vodi arbitriranju između mnoštva interesa, a posebice javnih interesa, ako ovdje sebi možemo dozvoliti upotrebu množine. Postupak procjene okoliša navodi nas da pažljivije pogledamo izazove koji se odnose na okoliš. Ovdje, naravno, ne govorimo o tome da treba zanijekati ono bitno u tim izazovima, već o tome da se treba zapitati na što se odnosi ovo prvenstvo koje može imati posljedice na urbanizam i na sadržaj planova. Odnosi li se to na politički izbor koji jasno dijele države članice ili na posljedice primjene nadležnosti zajednice po pitanju okoliša? Ne možemo isključiti niti drugu pretpostavku koju je istaknuo Yves Jégouzo s obzirom na pravo javnosti: „Činjenica da je zaštita okoliša postala nadležnost zajednice (...) snažno je doprinijela razvoju tog partikularizma prava na informaciju po pitanju okoliša, zakonski tekstovi su isticali svoju logiku koja nije ona koju francusko pravo usvaja u drugim područjima“. Da ta logika nije preuzeta, razlika u obradi dovodila bi do problema u pogledu temeljne zadaće uravnoteženosti interesa koje je u središtu urbanizma. Ako je procjena potrebna, zašto je ne primjenjujemo na sve ciljeve u planiranju? Zašto je ne primjenjujemo također i između ostalog na istraživanje socijalne mješovitosti? ${ }^{23}$

21 Drobenko, Bernard, Les paradoxes de la légalité en droit de l'urbanisme, PU Orléans, Paris, 2006., str. 195.

22 Ibid.

23 U tom smislu možemo primijetiti da je Španjolska prošlo proljeće usvojila zemljišni zakon koji sadrži članak koji proširuje sadržaj procjene planova. Prema izvješću Jesúsa del Olmo Alonsa, ,izvješće o 
Dr. sc. Bosiljka Britvić Vetma: Europski pogled na upravnopravnu zaštitu okoliša i urbanizam Zbornik radova Pravnog fakulteta u Splitu, god. 53, 2/2016., str. 497.-529.

Optimističan pogled na stvari ostavlja nadu da se posebna zaštita okoliša uključuje u razvoj i da će se metoda procjene uskoro proširiti na druge ciljeve obnovljenog javnog djelovanja, posebice u području planiranja.

\section{3. Usporedba nacionalnih i regionalnih sustava procjene}

Inspiracija je zajednička. Europske su zemlje podložne istim međunarodnim obvezama i obvezama zajednice, s izuzetkom Svicarske. Međutim, provedbe sustava procjene u različitim zemljama predstavljaju značajne razlike.

\section{3. 1. Provedba zajedničkih obveza}

Kvaliteta „diskursa o metodi“, koja se vezuje uz procjenu okoliša, čini da su različite međunarodne obveze i obveze zajednice, kao što su Konvencija iz Espoa i direktive, sjedinile zemlje u jednu vrstu zajedničkog identiteta. Tako se podrazumijeva da informacije prvo treba prikupiti. U svim slučajevima ${ }^{24}$ postoji popis minimalnih informacija koje treba prikupiti. Ovaj popis obuhvaća, osim predstavljanja radova, aktivnosti ili razmotrenog plana i početnog stanja okoliša, određivanje učinaka za koje tekst definira narav i područja, predstavljanje predviđenih alternativnih rješenja i razlog zašto je izabrano određeno rješenje, predviđene mjere za izbjegavanje, smanjenje i nadoknadu negativnih učinaka projekta, izvješće o poteškoćama do kojih je došlo u izradi procjene i, konačno, kako bi procjena bila dostupna javnosti, nestručni sažetak podataka. Isto vrijedi i za korištenje podataka. Predviđeno je barem određivanje pravca procesa koji će dovesti do javne odluke, uključujući zahtjev da se procjena provede prije donošenja odluke, da obuhvaća savjetovanje i sudjelovanje javnosti koje će se obaviti dovoljno rano u postupku kako bi to bilo stvarno korisno. U konačnici je predviđeno potvrđivanje da će, na kraju postupka, tijelo vlasti donijeti odluku i biti potpuno upoznato s uzrokom učinaka projekta na okolišs.

Sustavi procjene obuhvaćaju obveze i posebnosti koje opravdavaju kontekst i njegove ciljeve. Međutim, neslaganje, na kojem ćemo se zadržati, odnosi se na nacionalne i regionalne provedbe međunarodnih obveza i obveza zajednice. Ovo neslaganje u jednom dijelu nastaje zbog potrebe da se obveze o kojima je riječ uklope u posebni kontekst svake zemlje, posebno zbog institucionalne podjele odgovornosti i diobe ovlasti koje se odnose na urbanizam i okoliš, što opravdava da su direktive ravnodušne prema formalnim uvjetima svog prijenosa, u postojećim postupcima ili u ad hoc postupcima, u urbanističkom zakonodavstvu ili u zakonodavstvu koje se odnosi na procjenu okoliša. Međutim, neslaganje također može utjecati na bit sustava procjene, a možemo navesti nekoliko elemenata.

održivosti okoliša“ (informe de sostenibilidad ambiental) koji se veže za „dokumente o izvršenju radova“ mora uključivati i ,izvješće ili pisani rad o gospodarskoj održivosti“ (informe o memoria de sostenibilidad economica), ,koji će posebno procijeniti utjecaj zahvata na javne financije zbog postavljanja i održavanja potrebne opreme ili pokretanja i pružanja traženih usluga, kao i zbog kapaciteta i prilagodbe zemljišta u proizvodne svrhe“. Nakon toga, područje procjene nastoji se proširiti s okoliša na održivi razvoj.

${ }^{24}$ Uz zadršku za Direktivu 92/43/EEZ. 
Prvo, činjenica da su obveze koje imaju države obično minimalne, pa na taj način daju mogućnost da se odaberu ambiciozniji sustavi procjene, što su neke zemlje i iskoristile. Nadalje, obveze koje upućuju na dodatne mjere ili provedbe koje su izabrale zainteresirane zemlje. Kao što je određivanje materijalnog područja primjene procjene, koja se sastoji od popisa projekata koji su obvezno podložni procjeni na temelju europskog zakona i drugog popisa u okviru kojeg zemlja određuje projekte koji su također podložni procjeni. Na isti način, države određuju tijela vlasti koja djeluju u postupku procjene zbog „njihove specifične odgovornosti u području okoliša“. ${ }^{25}$ Isto tako, za postupak procjene, direktive samo određuju pravac koji državama ostavlja brigu oko određivanja dodatnih elemenata. Međunarodne obveze i obveze zajednice pogodne su za margine $\mathrm{u}$ tumačenju koje su još i šire ako imaju standardne oblike kao što su „vjerojatni značajni učinci“ ili „,relevantni aspekti“ koje treba predvidjeti u procjeni. Istina je da se te margine mogu smanjiti zbog stajališta Suda Europske unije u odnosu na direktivu iz 1985. i iz 1992. ${ }^{26}$

Među svim procjenama okoliša, koji se spajaju s postupcima odlučivanja što se uobičajeno primjenjuju na projekte, razlike se uglavnom odnose na izbor između dvije „stranke“. „Prva stranka“ bira pristup procjene koja ograničeno utječe na postupak. Ova prilagodbena stranka privilegira korištenje pravila, radije nego preispitivanje svakog pojedinačnog slučaja kako bi odredila projekte podložne procjeni i kako bi odredila stupanj preciznosti traženih podataka. Tijela vlasti koja se savjetuju u okviru njihove specifične odgovornosti, u području okoliša, najčešće su javnopravna tijela. Što se tiče postupka, tijelo vlasti koje donosi konačnu odluku uzima u obzir rezultate procjene, ali istovremeno primjenjuje svoju ovlast $u$ pogledu ocjenjivanja. Težište procjene nalazi u posebnom dokumentu projektnog predmeta koji je namijenjen tome da sudionicima u postupku odlučivanja i javnosti pruži dodatno objašnjenje. ${ }^{27}$

25 Haumont, Francis, L'encadrement juridique: fondements et objectifs du droit européen, RFDA, 2009., str. 649.

26 Ibid., str. 645.

27 Francusko i njemačko pravo urbanizma slikoviti su za prvu stranku, a pokazatelji nam kažu da su Grčka i Italija također to izabrali. Francuska je prije Direktive 85/337 imala sustav studije utjecaja koji je od tada izmijenila kako bi ispunila europske zahtjeve, posebice 1993. i 2006. Francuska je 2004. i 2005. značajno izmijenila uključivanje okoliša u dokumente o planiranju kako bi se uskladila s Direktivom 2001/42. Njemačka zauzima mjesto uz Francusku. Područje primjene sustava procjene okoliša predmet je zatvorenih popisa. U slučaju planova Baugesetzbuch sadržava iznimke od načela primjene strateške procjene okoliša za sve urbanističke planove. Zakon o studijama utjecaja (Gesetz über die Umweltverträglichkeitsprüfung) sadržava popis projekata koji su podložni studiji utjecaja. U slučaju planova, općina koja je plan izradila odlučuje o stupnju preciznosti procjene, a pri tome se temelji na standardu prilagodbe potrebama postizanja ravnoteže različitih interesa ( $\$ 21$ a. 4 BauGB). Vanjski nadzor procjene nije u rukama specijalizirane uprave nego u rukama tijela vlasti ovlaštenog za opći nadzor nad dotičnim planom. Njemačko pravo koje se primjenjuje na studije utjecaja od francuskih rješenja razlikuje se u dvije stvari: tijelo vlasti koje odlučuje o zahtjevu dužno je sastaviti studiju utjecaja, a ne podnositelj projekta; sudski nadzor je smanjen zbog općeg ograničenja u pravu zemlje, od pristupa sudnici do obrane subjektivnih prava u slučaju spora koji se odnosi na pojedinačni akt (ovo ograničenje ne vrijedi u slučaju planova za koje sudac može izvršiti nadzor nad izvršenjem procjene okoliša). Grčka je usvojila rješenja bliska onima Francuske i Njemačke. S jedne strane ističe se da ,većinu planova za prostorno planiranje i urbanizam (...) izrađuje ministarstvo za zaštitu okoliša, prostorno planiranje i javne 
Dr. sc. Bosiljka Britvić Vetma: Europski pogled na upravnopravnu zaštitu okoliša i urbanizam Zbornik radova Pravnog fakulteta u Splitu, god. 53, 2/2016., str. 497.-529.

„Druga stranka“ okuplja zemlje koje su namjeravale dati svu širinu procjeni tako što će sačuvati više ili manje važno mjesto za preispitivanje pojedinačnih slučajeva kada se radi o projektima koje je potrebno preispitati za određivanje traženih podataka, razvijajući cijeli postupak procjene okoliša tako da javnopravno tijelo nadležno za ,zaštitu okoliša“ (ili tijela koja ga čine) ima ključnu ulogu. Težište procjene temelji se na iskorištavanju prikupljenih podataka. ${ }^{28}$

\section{RAZLOG POSTOJANJA DIREKTIVE 2001/42/EZ O PROCJENI UČINAKA POJEDINIH PLANOVA I PROGRAMA NA OKOLIŠ}

Poznato je da Direktiva 85/337/EEZ od 27. lipnja 1985. o procjeni učinaka određenih javnih i privatnih projekata na okoliš ${ }^{29}$ nije namijenjena primjeni na procjenu okoliša koja prethodi planovima i programima. Tek je iznimno Sud Europske unije procijenio da se Direktiva 85/337/EEZ primjenjuje na usvajanje urbanističkih planova. U svojoj presudi od 18. lipnja $1998 .{ }^{30}$ Sud je sankcionirao usvajanje urbanističkog plana zato što usvajanju nije prethodila procjena okoliša i na taj način je došlo do kršenja Direktive 85/337/EEZ. Sud je ocijenio da se usvajanje plana moralo uzeti u obzir kao suglasnost za izvođenje radova u smislu članka 1., stavka 2. Direktive 85/337/EEZ tj. „odlukom nadležne vlasti koja izvođaču daje pravo da nastavi s dotičnim projektom“. U nizozemskom pravu, stupanje na snagu ovog plana omogućavalo je izvođaču da izvodi radove, a da ne treba zatražiti upravnu suglasnost za nastavak radova. Prema tome, iza ovog se urbanističkog plana, u stvari, nalazila dozvola za provođenje projekta. Iskustvo procjene okoliša

radove, tako da u posljednjem stupnju procjenu okoliša provode različite službe u tom ministarstvu“, s druge strane, ,vanjski nadzor (...), načelno, vrši se u okviru zahtjeva zbog nezakonitosti pred Državnim savjetom“. Razlika u odnosu na francuski i njemački sustav odnosi se na to da se područje primjene procjene kombinira s korištenjem popisa planova koji se obvezno moraju predati, a za ostale, naročito one „koji određuju uporabu malih površina na lokalnoj razini“ (članak 3.3. Direktive 2001/42), provodi se postupak na kraju kojeg ravnatelj odjela za zaštitu okoliša u ministarstvu odlučuje o tome jesu li planovi podložni procjeni okoliša ili ne. Lebreton, Jean-Pierre, L'évaluation environnementale et le droit de l'urbanisme: perspective comparative, RFDA, Paris, 2008.

28 Belgija se odlučno obvezala na opširne procjene okoliša, ponad zahtjeva iz direktiva. Prije svega, pravila koja se primjenjuju na podvrgavanje procjeni okoliša i stupanj preciznosti procjene daju značajno mjesto individualiziranoj procjeni određenog projekta. Isto vrijedi za studije utjecaja budući da, prema zakoniku o zaštiti okoliša, ,izdavanje svake dozvole ovisi o provođenju sustava procjene učinaka“ (a pod dozvolom se misli na dozvole u pogledu okoliša, urbanizma i jedinstvene dozvole u smislu ta dva zakona). Za one dozvole koje nisu podložne obveznoj studiji utjecaja, nadležno tijelo donosi odluku, s obzirom na bilješku koju sastavlja podnositelj zahtjeva, ako to tijelo smatra da je bilješka dostatna za izmjeru učinaka na okoliš, u suprotnom, nadležno tijelo odlučuje da je potrebno provesti studiju utjecaja. Što se tiče sadržaja bilješke i studije, on mora biti predmetom prethodnog mišljenja: u prvom slučaju, to mišljenje traži podnositelj zahtjeva kod nadležnog tijela, a u drugom slučaju potrebna su dva mišljenja, nadležnog tijela i javnosti. U slučaju planova, pitanje područja primjene studije utjecaja, čini se, ne postavlja se u onoj mjeri u kojoj je studija obvezna za sve urbanističke planove (ako se ne radi o pitanju podvrgavanja prostornih shema bez izravnog suprotstavljanja za koje valonski i briselski zakoni daju suprotne odgovore). Lebreton, Jean-Pierre, L'évaluation environnementale et le droit de l'urbanisme: perspective comparative, RFDA, Paris, 2008.

29 Ibid.

30 Sud Europske unije, 18. lipnja 1998. Burgemeester en wethouders van Haarlemmerlieden en Spaarwude i ostali protiv Gedeputeerde Staten van Noord-Holland. 
koje se provodi na temelju Direktive 85/337/EEZ pokazalo je da se u postupku odlučivanja kasnilo $\mathrm{s}$ tom procjenom. Uzmimo za primjer projekt integrirane kemijske tvornice koja, u skladu s primjenom Dodatka I. direktive 85/337/EEZ, po službenoj dužnosti podliježe prethodnoj procjeni okoliša, a radi se o projektu koji se izvodi na području plana korištenja zemljišta koji je posebno rezerviran za integrirane kemijske tvornice. Jasno je da procjena okoliša koja prethodi davanju upravnih suglasnosti polazi od toga da je projekt sukladan korištenju plana. A priori, analiza okoliša u pogledu izbora korištenja urbanističkog plana ne spada u predmet procjene okoliša koja prethodi davanju upravnih suglasnosti. Nadalje, veliki problem za okoliš mogao bi biti izbor lokacije u određenom području. Zbog toga se ocijenilo da bi procjenu okoliša trebalo provesti mnogo prije odluke tj. tijekom izrade planova o upotrebi zemlje. To je ratio legis Direktive 2001/42/EZ od 27. lipnja 2001. o procjeni učinaka pojedinih planova i programa na okoliš.

U okviru ovog rada ispitat ćemo opseg Direktive 2001/42/EZ. Zasigurno se jako puno može reći na tu temu, ali s obzirom na dodijeljeni prostor, odabrali smo teme koje se odnose na opću temu ovog rada i koje nam se čine najrelevantnijima.

\subsection{Opće napomene}

Prije nego što pristupimo ispitivanju Direktive 2001/42/EZ u pravom smislu te riječi, želimo iznijeti dvije opće napomene. Prva se odnosi na utemeljenost direktive, a druga na sudsku praksu Suda Europske unije.

\section{1. 1. Utemeljenost Direktive 2001/42/EZ}

Direktiva 2001/42/EZ izričito je utemeljena na članku 175., stavku 1. Ugovora o osnivanju Europske zajednice. ${ }^{31}$ Kao što znamo, Ugovor o osnivanju Europske zajednice obuhvaća dva glavna temelja za pravne tekstove o okolišu. Kako se Direktiva temelji na članku 175., tj. u okviru posebne nadležnosti za okoliš, tako direktiva predstavlja minimalni pravni okvir. ${ }^{32}$ Drugim riječima, ništa ne sprečava zemlje članice da usvoje strože nacionalne pravne propise. S druge strane, kada se direktiva temelji na članku 95. istog Ugovora, tj. u okviru mjera usklađivanja nacionalnih zakonodavstava, manevarski prostor država je ograničen. Pretpostavka je da, čim se traži usklađivanje zakonodavstava kako bi se uklonilo narušavanje tržišnog natjecanja, tada to znači da države ne mogu, osim iznimno, usvojiti stroge interne pravne propise.

Budući da je Direktiva 2001/42/EZ utemeljena na članku 175., prema tome države ništa ne sprečava da usvoje strože pravne propise nego one koje nalaže direktiva.

31 Day, C., Mise en oeuvre de la directive 2001/42 relative à l'évaluation des incidences de certains plans et programmes sur l'environnement, Commission, 2003., str. 6-7.

32 Josette, Debroux, Le choix de la base juridique dans l'action environnementale de l'Union européenne, AJDA, Paris, 1995., str. 383. 


\section{1. 2. Sudska praksa Suda Europske unije}

Do sada, Direktiva 2001/42/EZ nije bila predmet presuda Suda koje bi mogle pomoći u tumačenju njezinog opsega. Trenutačno, Sud je donio samo presude u pogledu država članica koje nisu prenijele direktivu u predviđenom roku. ${ }^{33}$ Međutim, postoje među mehanizmima Direktive 85/337/EEZ i Direktive 2001/42/ EEZ brojne analogije na koje ćemo se još vratiti. To ima za posljedicu da je sudska praksa Suda o Direktivi 85/337/EZ relativno obilna i njezin prijenos u unutarnje pravo sluti na sudsku praksu o Direktivi 2001/42/EZ. Isto razmišljanje vrijedi za članak 6., stavak 3. i 4. Direktive 92/43/EEZ o staništima koja, kao što smo već vidjeli, nalaže odgovarajuću procjenu za određene planove i programe. Evidentno je da će se stroga sudska praksa Suda Europske unije o poštovanju Direktive 92/43/EEZ odraziti na tumačenje opsega određenih odredbi Direktive 2001/42/ EZ. U sljedećim godinama, Sud bi, dakako, trebao donositi presude koje će imati strogost presuda koje su donesene s obzirom na Direktivu 85/337/EEZ i Direktivu 92/43/EEZ. U tom kontekstu, zanimljivo je skrenuti pozornost na presudu koju je Sud donio 2005., a u kojoj ističe kako kršenje strožih nacionalnih pravila nego onih što ih nalaže Direktiva 85/335/EEZ predstavlja kršenje same Direktive. ${ }^{34}$ Ova sudska praksa, prenesena u Direktivu 2001/42/EZ, podrazumijeva da bi se kršenje nacionalnih pravila, koja su stroža nego što to nalaže sama direktiva, mogla usporediti s kršenjem same direktive.

\section{2. Posebne napomene}

Kao što je već spomenuto, Direktiva 2001/42/EZ izaziva brojna pitanja koja zaslužuju dublju analizu. U okviru ovog članka, ograničit ćemo se na područje njezine primjene, iako ćemo se posvetiti određenim temama koje su vezane za procjenu okoliša u užem smislu i praćenje okoliša koje nalaže Direktiva.

\section{2. 1. Područje primjene}

Jedno od pitanja koje postavlja Direktiva 2001/42/EZ jest koji su to planovi i programi, a koji su, posebno, urbanistički planovi sadržani u direktivi, koji su u tom smislu podložni prethodnoj procjeni učinaka na okoliš. Prema članku 3., stavku 1. Direktive 2001/42/EZ, ${ }^{35}$ procjena okoliša mora se izvršiti za planove i programe koji bi mogli imati značajne učinke na okoliš. Navode se dvije vrste planova i programa: niz planova i programa koji se spominju eksplicitno, i „ostali““ planovi koji bi mogli imati značajne učinke na okoliš. Osvrnut ćemo se samo na prve zato što drugi, u načelu, nisu urbanistički planovi. Direktiva 2001/42/EZ na

33 Sud Europske unije, 26. listopada 2006. Komisija protiv Finske, 26. listopada 2006. Komisija protiv Luksemburga, 7. prosinca 2006. Komisija protiv Belgije, 24. ožujka 2007. Komisija protiv Portugala, 8. studenog 2007. Komisija protiv Italije.

34 Sud Europske unije, 6. lipnja 2005. Komisija protiv Italije.

35 http://ec.europa.eu/environment/nature/natura2000/management/docs/Estuaries-FR.pdf 
prvom mjestu navodi planove i programe koji kumulativno ispunjavaju sljedeće uvjete:

- koji podliježu izradi ili usvajanju od strane tijela na nacionalnoj, regionalnoj ili lokalnoj razini; Vlade;

- koje je tijelo izradilo za usvajanje u zakonodavnom postupku Parlamenta ili

-koji su propisani zakonodavnim, regulatornim ili administrativnim odredbama;

- koji su izrađeni za poljoprivredu, šumarstvo, ribarstvo, energetiku, industriju, prijevoz, gospodarenje otpadom, gospodarenje vodama, telekomunikacije, turizam, prostorno planiranje ili uporabu zemlje i koji određuju okvir u kojem provedba projekata navedenih u prilozima I. i II. Direktive 85/337/EEZ dovodi do procjene učinaka, ili za koje je, s obzirom na moguć učinak na područja, utvrđeno da zahtijevaju procjenu na temelju Direktive 92/43/EEZ o staništima.

Drugim riječima, direktiva nalaže da svaki plan ili program mora biti izrađen na temelju zakona, uredbe ili upravne odluke koja će predstavljati okvir u kojem će se nalaziti projekt preuzet s popisa Direktive 85/337 EEZ, koji će biti podložan procjeni učinaka ili koji će biti od onih projekata koji zahtijevaju ovu procjenu u skladu s direktivom o staništima, ili će biti podložan prethodnoj procjeni u obliku izvješća o učincima na okoliš.

Ova odredba i uvjeti koji su njome utvrđeni izaziva nekoliko komentara. Prva primjedba odnosi se na sami pojam ,plana“ i ,programa“. Direktiva ne definira ove pojmove već navodi tri uvjeta koja oni moraju ispuniti. Kao što praktični vodič o provedbi direktive, što ga je Komisija objavila, ukazuje na to da naziv (,plan“, „program“, „strategija“, ,smjernice“ itd.) ne predstavlja dovoljno pouzdan izraz. Po analogiji s pojmom projekta koji rabi Sud Europske unije u skladu s Direktivom 85/337/EEZ o procjeni učinaka određenih javnih i privatnih projekata na okoliš, Komisija preporučuje široko tumačenje pojma „planova i programa“ u smislu Direktive 2001/42/EZ.

Što se tiče prvog uvjeta iz direktive, jasno je navedeno da u područje primjene direktive ulaze planovi i programi koje je izradilo, usvojilo ili odobrilo tijelo javne vlasti. Pojam ,tijelo javne vlasti“ također nije definirano. Komisija se referira na činjenicu da pojam ,tijelo javne vlasti“ u sudskoj praksi Suda ima široko područje primjene. Ovaj uvjet obično ne dovodi do tumačenja urbanističkih dokumenata koje ,tijelo javno vlasti“ ne izrađuje, ali ih usvaja ili odobrava.

Drugi uvjet koji se odnosi na činjenicu da je plan ili program „propisan“ zakonodavnim, regulatornim ili upravnim odredbama također može dovesti do rasprave. Ovaj uvjet nije predviđen u početnim inačicama prijedloga direktive, već se prvi put pojavljuje u inačici od 30. ožujka 2000. Obrazloženje Vijeća je sibilsko, nejasno: „Definicija ,planova i programa“ je izmijenjena i sada određuje da su obuhvaćeni samo planovi i programi koje propisuju zakonodavne,

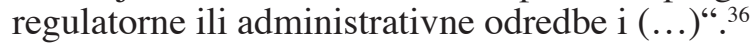

36 Day, C., Mise en oeuvre de la directive 2001/42 relative à l'évaluation des incidences de certains plans et programmes sur l'environnement, Commission, 2003., str. 6-7. 
Izbor riječi „propisuje“ ${ }^{37}$ važan je jer može dovesti do tumačenja. U načelu, trebao bi značiti da se direktiva odnosi samo na planove i programe čije usvajanje predstavlja obvezu ,tijela javnih vlasti“, drugim riječima, iz izraza „,propisuje“ mogli bismo zaključiti da planovi i programi predviđeni zakonom ili uredbom, ali čije usvajanje nije obvezatno, ne ulaze u područje primjene direktive.

Čini se da ovo tumačenje na prvi pogled ne odgovara ratio legisu direktive, jer kako možemo zamisliti da usvajanje plana koji predstavlja okvir za provođenje projekta podložnog procjeni učinaka, a radi se o trećem uvjetu na koji ćemo se još vratiti, može izmaknuti prethodnoj procjeni učinaka na okoliš zbog jedinog razloga tj. zato što njegova izrada nije obvezatna? $\mathrm{K}$ tome, većina planova $\mathrm{i}$ programa na koje se odnose prava država članica izmakla bi procjeni okoliša i na taj bi način ostavili Direktivu 2001/42/EZ gotovo bez učinka. To bi bilo posebno naglašeno u pravu urbanizma jer rijetki su nacionalni zakoni o urbanizmu koji zahtijevaju izradu urbanističkog plana.

Vjerojatno bi trebalo izraz „propisuje/zahtijeva“ čitati u smislu pojma „predviđeno/obuhvaćeno“. Engleska verzija Direktive u kojoj se koristi izraz „required“ nije nam baš od koristi. Međutim, talijanska verzija koja koristi izraz „previsti“" nedvosmisleno ide u tom smjeru.

K tome, čini se da Komisija u svom praktičnom vodiču za Direktivu 2001/42/ EZ jasno ostaje pri tome da su planovi iz direktive oni i samo oni koje propisuju zakonodavne, regulatorne ili upravne odredbe. „Ako se ovi uvjeti ne poštuju“", kaže Komisija, „tada se direktiva ne primjenjuje. Ovi „,dobrovoljni“ planovi i programi obično nastaju zato što se zakonodavstvo oblikuje na temelju permisivnih izraza ili zato što je određeno tijelo odlučilo izraditi plan koji se odnosi na djelatnost koja nije regulirana. S druge strane, ako tijelo vlasti nije obvezno izraditi plan, ukoliko se određeni preduvjeti poštuju, ovaj plan bi vjerojatno bio podložan direktivi tek kada su ispunjeni uvjeti (i kada su ispunjene obveze iz članaka 2. i 3.). Očito je prepušteno na volju državama članicama, s obzirom na njihove vlastite nacionalne sustave, da idu iznad minimalnih zahtjeva ako to žele.“

Što se tiče trećeg uvjeta, odnosno činjenice da se može odnositi na određene sektore aktivnosti ili može imati učinke na područje zaštićeno mrežom Natura $2000,^{38}$ on potvrđuje veliku važnost koju ima ova direktiva. Bilo je predviđeno u početku da se direktiva odnosi na planove i programe za prostorno planiranje. Nakon izmjena koje je sugerirao Europski parlament, područje primjene proširilo se na sve planove ili programe koji su izrađeni u nabrojanim sektorima, a da se ne mora postaviti pitanje o tome ulazi li taj sektor u definiciju prostornog planiranja, što je ionako pojam koji države shvaćaju na različite načine. No, sigurno je u svakom slučaju da prostorno planiranje i urbanizam predstavljaju prvi sektor primjene direktive. Karakteristično je u tom smislu utvrditi da se primjeri iz

37 Riječ „propisuje“ nalazi se u hrvatskom prijevodu direktive. 2005.

38 Février, J.-M., Le juge communautaire et la notion de projet sur un site Natura 200, AJDA, Paris,

Vidi i http://ec.europa.eu/environment/nature/natura2000/management/docs/Estuaries-FR.pdf 
Komisijinog praktičnog vodiča često odnose na urbanizam i prostorno planiranje. Primijetit ćemo da Komisija isključuje iz članka 3., stavka 2. direktive, a temeljeći se na desetom uvodnom obrazloženju, pretpostavku o značajnim učincima na okoliš koja dokazuje da su planovi i programi s tog popisa podložni procjeni okoliša. Drugim riječima, činjenica da stavak 1. članka 3. sadrži načelo po kojem se ,procjena okoliša (...) provodi za planove i programe iz stavaka 2., 3. i 4. koji bi mogli imati značajne učinke na okoliš, po mišljenju Komisije treba tumačiti na sljedeći način: „Osim slučajeva predviđenih u stavku 3., države članice ne mogu slobodno odrediti bi li planovi i programi iz stavka 2. mogli imati značajne učinke na okoliš: direktiva pretpostavlja da planovi i programi imaju tu vrstu učinaka“.

Premda možemo raspravljati o dvosmislenosti stavka 1. članka 3., ratio legis članka 3. u svojoj cijelosti nije sporan. To je važno za planove prostornog uređenja urbanih i ruralnih područja i za planove o upotrebi zemlje iz stavka 2. a) koji automatski podliježu procjeni okoliša osim ako nisu izuzeti primjenom stavka 3 . U nastavku ćemo ispitati ovaj mehanizam izuzimanja.

Članak 3., stavak 2. direktive oblikuje ovo opće načelo tako što kaže da su, u odgovarajućim sektorima, podložni obvezama iz direktive samo oni planovi i programi koji definiraju okvir u kojem projekti iz Direktive 85/337/EEZ mogu dobiti suglasnost ili oni koji su podložni procjeni na temelju Direktive 92/43/EZ.

Što se tiče prvih, tj. onih koji se odnose na projekte iz Direktive 85/337/EZ, imamo dvije primjedbe.

Prva se odnosi na doseg riječi „koje određuju okvir za buduće odobravanje provedbe projekata (...)“. Šesto uvodno obrazloženje direktive govori o planovima i programima „kojima se određuje okvir za buduće odobravanje projekata“. Čini se da je ova formulacija vrlo široka da bi mogla obuhvatiti planove i programe čiji je opseg indikativan zbog toga što oni predstavljaju „okvir“ za odluke o odobrenjima ili suglasnostima. „Tijelo javne vlasti“ će a priori poštovati dokumente koji se odnose na planove ili programe, ukoliko su indikativni. Ako ih „tijelo javne vlasti“" mora odbaciti, u načelu, ono mora obrazložiti razloge tog odbacivanja. U svakom slučaju, to je rješenje koje implicitno sadrži praktični vodič koji, u ranije spomenutom izvatku, među primjerima „smjernica“ navodi i indikativne dokumente. To je također i poluslužbeno izrečeni odgovor Opće uprave za okoliš Europske komisije na pitanje koje je 2002. godine postavio valonski ministar za urbanizam i okolišs. ${ }^{39}$ Prema tome, ovi indikativni dokumenti predstavljaju „okvir“ u smislu direktive. Praktični vodič Komisije sadrži niz komentara o smislu riječi „definiraju okvir“. U svakom slučaju, jasno je da su planovi o upotrebi zemlje, koji često predstavljaju planove o prostornom planiranju i urbanizmu, u pravom smislu riječi, planovi koji određuju okvir projekata iz Direktive 85/337/EEZ.

Druga primjedba odnosi se na projekte iz dodataka I. i II. Direktive 87/338/ EEZ od 27. lipnja 1985. o procjeni učinaka određenih javnih i privatnih projekata na okoliš, koja je izmijenjena Direktivom 97/11/EZ od 3. ožujka 1997. Ova

39 http://ec.europa.eu/dgs/environment/index_en.htm 
direktiva, kao što ćemo to moći preispitati u dijelu koji se bavi urbanističkim dozvolama, klasificira projekte u dvije kategorije.

- Oni iz dodatka I. po službenoj su dužnosti predmet procjene učinaka na okoliš koje mogu prouzročiti.

- Oni iz dodatka II. nisu predmet procjene ukoliko država članica smatra da ne bi mogli imati značajan učinak na okoliš.

Direktiva 2001/428/EZ ne sadrži to pojmovno razdvajanje. Drugim riječima, od trenutka u kojem plan ili program predstavlja okvir za provedbu projekta, iako taj projekt nije obuhvaćen dodatkom II. i posljedično ne bi mogao imati značajan učinak na okoliš, taj je plan ili program podložan prethodnoj procjeni učinaka na okoliš. Isto vrijedi i ako plan ili program izričito ne spominju taj projekt, ali bi mogli omogućiti njegovo ostvarenje. Uzmimo za primjer usvajanje plana koji predviđa područje za gospodarsko-industrijsku djelatnost. Iako ne znamo koje bi se industrije mogle smjestiti u to područje, upravo zbog toga što plan potencijalno omogućuje postrojenja industrijske djelatnosti iz dodatka II Direktive 85/337/EZ, on je podložan prethodnoj procjeni okoliša.

Što se tiče planova i programa koji su podložni procjeni učinaka temeljem Direktive 92/43/EEZ od 21. svibnja 1991. o očuvanju prirodnih staništa i divlje faune i flore, tzv. Direktiva o staništima 2001/42/EZ ne pruža nikakve izmjene načela prema kojem ,svaki plan (...) koji nije izravno povezan s upravljanjem područjem ili potreban za njegovo upravljanje, ali bi na njega mogao imati značajan utjecaj, bilo pojedinačno, bilo u kombinaciji s ostalim planovima ili projektima, predmet je ocjene prihvatljivosti utjecaja koje bi mogao imati na to područje, s obzirom na ciljeve očuvanja područja“. Sama po sebi direktiva ne mijenja područje primjene obveze koja proizlazi iz Direktive 92/43/EEZ. Naprotiv, ona razjašnjava ono što se podrazumijeva pod pojmom „odgovarajuća procjena“: procjena okoliša koju nalaže Direktiva 2001/42/EZ zapravo predstavlja odgovarajuću procjenu koju nalaže Direktiva 92/43/EZ.

Ako Direktiva 2001/42/EZ ne mijenja područje primjene Direktive 92/43/ EEZ u pogledu planova koji su podložni odgovarajućoj procjeni, sudska praksa Suda daje važne upute u pogledu projekata i neizravno, u pogledu planova koji zahtijevaju tu procjenu. U svojoj presudi Mer de Wadden, Sud Europske unije smatrao je da, zbog toga što članak 6., stavak 3. omogućuje nadležnom tijelu vlasti da izda dozvolu tek nakon što se uvjerilo da projekt „,neće negativno utjecati na cjelovitost dotičnog područja“, to dovodi do obveze provođenja odgovarajuće procjene čim postoji i najmanja sumnja na utjecaj projekta. Ono što vrijedi za projekt, vrijedi i za plan.

Imajmo na umu da odluka parlamenta br. 884/2004/EZ i vijeća od 29. travnja 2004. koja je izmijenila odluku br. 1692/96/EZ o smjernicama zajednice za razvoj transeuropske prometne mreže izričito predviđa da države članice moraju provesti procjenu koju zahtijeva Direktiva 2001/42/EZ za planove i programe koji se odnose na projekt od zajedničkog interesa. 


\section{3. Iznimke od obveze prethodne procjene}

Direktiva 2001/42/EZ predviđa iznimke od obveze prethodne procjene ranije navedenih planova i programa. Među njima, zadržat ćemo se na onima koje se odnose na planove i programe bez značajnih učinaka, a koji predstavljaju iznimke koje bi se mogle primjenjivati na urbanističke dokumente. Radi se o planovima i programima koji ulaze u područje primjene članka 3., stavka 2., ali koji se ne odnose na uporabu malih površina na lokalnoj razini ili na manje promjene planova i programa koji su podložni izvješću o učincima. Procjena okoliša nalaže se samo kada države članice utvrde da bi oni mogli imati značajne učinke na okoliš.

\section{3. 1. „Male površine na lokalnoj razini““}

Praktični vodič Komisije navodi što se podrazumijeva pod „malim površinama na lokalnoj razini“: Smisao „malih“u rečeničnom dijelu „,male površine na lokalnoj razini" treba definirati na način da se uzmu u obzir razlike između država članica i vjerojatno će biti potrebno odlučivati o pojedinačnim slučajevima. Ovaj izraz treba tumačiti na temelju vlastitog suda. Predložena vrsta plana ili programa može biti građevinski plan koji za određenu ograničenu površinu sadrži detaljan opis načina na koji objekti moraju biti izgrađeni i, na primjer, koje visine, širine ili dizajna moraju biti. Također je teško odrediti smisao izraza „lokalni“. Jezik direktive ne uspostavlja jasnu vezu s lokalnim tijelima vlasti, već riječ „razina“ podrazumijeva razliku u odnosu primjerice nacionalne ili regionalne razine. Cjelokupni rečenični dio („male površine na lokalnoj razini“") jasno ukazuje da se sveukupna površina lokalnog tijela vlasti ne može isključiti (osim ako ona sama nije manja). U nekim državama članicama, zemljopisno područje lokalnih tijela vlasti može, zapravo, biti vrlo široko i iznimka primjenjiva na to cjelokupno područje predstavljala bi veliki propust u području primjene direktive. „Međutim, bitan kriterij za primjenu direktive nije veličina obuhvaćenog zemljopisnog područja, već značajni učinci koje bi mogao imati plan ili program na okoliš. Plan ili program za koji država članica ocijeni da bi mogao imati značajne učinke na okoliš podložan je procjeni okoliša, iako određuje samo uporabu male površine na lokalnoj razini. Do slične primjedbe došlo je u predmetu C-392/96, Komisija protiv Irske, u kojoj je Sud Europske unije odlučio, utvrđujući pragove koji se odnose na dimenzije projekata, „bez razmatranja njihove naravi i lokacije“, da je država članica premašila marginu diskrecije kojom raspolaže. „Projekti bi mogli imati značajne učinke na okoliš zbog njihove naravi ili lokacije." Iz ovog komentara možemo izvući dvije pouke. Prva je da koncept „,male površine na lokalnoj razini“ može, usprkos svemu, obuhvaćati šire zemljopisno područje budući da Komisija ne isključuje samo plan upotrebe zemlje, koji bi se, na primjer, odnosio na cjelokupnu površinu općine, a ulazi u koncept „male površine na lokalnoj razini“ ukoliko je površina općine mala. Nadalje, možemo dijeliti mišljenje Komisije, glavni kriterij za određivanje radi li se o maloj površini na lokalnoj razini jesu potencijalni značajni učinci plana ili programa. Drugim riječima, plan upotrebe zemlje čiji bi opseg obuhvaćao odredište koje nije građevinsko, mogao bi se smatrati planom koji se odnosi na 
„malu površinu na lokalnoj razini““ iako je njegova površina velika, dok drugi plan koji bi na ograničenoj površini predviđao upotrebu u poduzetničkoj zoni Seveso ne bi mogao biti dio koncepta „male površine na lokalnoj razini“.

\section{3. 2. Manje promjene}

Nema sumnje da su promjene planova i programa podložne istom sustavu kao i njihova izrada. Članak 2. a) direktive izričito se odnosi na njih. Članak 3., stavak 3., ipak omogućuje manje promjene koje izmiču prethodnoj procjeni okoliša. Komisija o konceptu „manjih promjena“ kaže sljedeće: „Na isti način, izraz „manje promjene“ trebalo bi se razmatrati u kontekstu plana ili programa koji je predmet promjene i u kontekstu vjerojatnosti u pogledu značajnih učinaka na okoliš. Opća definicija „manjih promjena“ vjerojatno ne bi služila ničemu. U skladu s definicijom „planova i programa“ u članku 2., „njihove promjene“ potencijalno mogu ući u područje primjene direktive. Članak 3., stavak 3., razjašnjava ovo, prihvaćajući da promjena može biti toliko mala da je slabo moguće da će imati značajne učinke na okolišs, ali zahtijeva da promjena podliježe procjeni bez obzira na njezinu veličinu, kada bi promjena plana ili programa mogla imati značajne učinke na okoliš. Važno je imati na umu da sve promjene ne moraju biti predmetom nove procjene učinaka u smislu direktive jer ona ne zahtijeva pokretanje novog postupka ako promjene ne bi imale značajne učinke na okoliš. “ Prema tome, direktiva predviđa da države članice imaju marginu diskrecije kako bi izuzele navedene planove od procjene okoliša.

\section{3. 3. Pretpostavka o izostanku učinaka na okoliš}

Za ove planove, koji se odnose na male površine na lokalnoj razini ili na manje promjene, postoji ,pretpostavka o izostanku učinaka na okoliš“ u stavcima 3. i 4. članka 3. isti izraz: ako država članica utvrdi ili odredi da bi planovi koji se odnose na male površine na lokalnoj razini ili manje promjene ovih planova „mogli imati značajne učinke na okoliš“", tada je potrebna procjena njihovih učinaka na okoliš.

U stvarnosti se radi o sličnoj formulaciji koju pronalazimo u članku 4., stavku 2., Direktive 85/337/EEZ o procjeni učinaka određenih javnih i privatnih projekata na okoliš. U svojoj staroj formulaciji koja je prethodila njezinoj izmjeni Direktivom 97/11/EZ, Direktiva 85/337/EZ predviđala je da su projekti iz dodatka II. podložni procjeni „kada države članice smatraju da to zahtijevaju njihova svojstva“" ${ }^{40}$ Sud Europske unije u svojoj presudi, donesenoj o staroj inačici članka 4. Direktive 85/337/EZ, naveo je da „odluka kojom nadležno nacionalno tijelo javne vlasti smatra da svojstva projekta ne zahtijevaju da podliježe procjeni svojih učinaka na okoliš mora sadržavati ili imati u prilogu sve elemente koji omogućuju da se provjeri temelji li se ona na odgovarajućoj provjeri, izvršenoj u skladu sa zahtjevimaiz direktive 85/337“. Nezavisni odvjetnik Ruiz-Jarabo Colomer u svojim

40 Josette, Debroux, Le choix de la base juridique dans l'action environnementale de l'Union européenne, AJDA, Paris, 1995., str. 383. 
zaključcima ističe kako „upravna odluka koja niječe da, zbog svojih specifičnosti, projekt može negativno utjecati na okoliš, zahtijeva obrazloženje. Prema već navedenom općem pravilu svaka gradnja prije nego što bude odobrena mora proći procjenu svog opsega, tako da, ako određeni postupak nije u skladu s područjem primjene tog zahtjeva zbog svoje naravi, koja nije štetna, potrebno je navesti razloge koji to potvrđuju“. Također je u bilješci naveo da „šutnja nije prihvaćena kao odgovor koji bi isključio potrebu za provedbom studije učinka infrastrukturne gradnje na okoliš“. Sve upućuje na zaključak kako će se ova sudska praksa po analogiji primjenjivati i na Direktivu 2001/42/EZ. Drugim riječima, ako nadležno tijelo javne vlasti smatra da treba primijeniti mehanizam izuzimanja iz članka 3 ., stavka 3. ili 4., ono će trebati obrazložiti svoju odluku, po potrebi vraćanjem na već izrečena mišljenja o izostanku očekivanih značajnih učinaka. To je važno, a tim više što se čini da to ide u suprotnom smjeru teksta Direktive 2001/42/EZ, koji favorizira tumačenje u smislu pretpostavke izostanka značajnog učinka. Ako nacionalna tijela javne vlasti moraju dokazati izostanak značajnih učinaka kako bi mogli izuzeti druge planove iz procjene, manje promjene ili planove koji se odnose na manje površine na lokalnoj razini, tada se preokreće teret dokazivanja. Budući da je to tako, treba istaknuti kako se zahtjev za obrazloženjem nalazi u drugoj odredbi članka 3., u ovom slučaju u stavku 7., koji se odnosi na postupak izuzimanja od procjene. Ova odredba nalaže državama članicama da omoguće javnosti uvid u razloge zbog kojih nije potrebno provesti procjenu okoliša“. Što opet nalaže formalno obrazloženje ili referiranje na mišljenja ili izvješća.

Članak 3., stavak 5. Direktive navodi da države članice određuju može li određeni plan ili program biti izuzet ,,i to ili preispitivanjem pojedinačnih slučajeva ili određivanjem vrsta planova i programa ili kombinacijom oba pristupa. U tu svrhu države članice u svim slučajevima uzimaju u obzir odgovarajuće kriterije utvrđene u dodatku II. kako bi osigurale da se planovi i programi s mogućim značajnim učincima na okoliš obuhvate ovom direktivom“.

Radi se o mehanizmu preuzetom iz Direktive 85/337/EEZ: za projekte navedene u dodatku II. ove direktive, države članice određuju, na temelju preispitivanja pojedinačnih slučajeva ili na temelju pragova ili kriterija koje utvrđuje svaka država ili primjenjujući ova dva postupka, je li projekt podložan procjeni okoliša zato što bi mogao imati negativan učinak na okoliš.

Sudska se praksa Suda Europske unije u više navrata očitovala o opsegu ove odredbe u interno usvojenim propisima većina država članica. Nacionalna prava su zapravo često birala usvajanje popisa projekata koji su po službenoj dužnosti oslobođeni ili, naprotiv, podložni procjeni okoliša koja se zahtijeva temeljem Direktive 85/337/EZ. Projekt se nalazi ili ne nalazi na popisu, tako da nije potrebno ispitivati pojedinačne slučajeve i preispitivati zahtijevaju li oni procjenu okoliša. Stav Suda iz Luxembourga je da direktiva „ne povjerava državama članicama ovlast da sveobuhvatno i konačno izuzmu jedan ili više navedenih razreda iz moguće procjene jer spomenuti kriteriji i/ili pragovi nemaju svrhu unaprijed izuzeti obvezu procjene određenih razreda projekata iz dodatka II., 
koji se predviđaju na području države članice, već im je jedina svrha da olakšaju procjenu konkretnih svojstava koje ima projekt za koji treba odrediti je li podložan navedenoj obvezi“. 41

U svojoj presudi od 21. rujna 1999. Sud je osudio Irsku, jer nije na sukladan način prenijela članak 4., stavak 2., na temelju sljedećeg obrazloženja: „Država članica koja je uspostavila kriterije i/ili prag tako da, u praksi, svi projekti budu unaprijed izuzeti od obveze provedbe studije učinaka, premašuje marginu diskrecije koju ima na temelju članka 2., stavka 1. i 4., stavka 2. direktive, osim ako se svi isključeni projekti mogu razmatrati na temelju sveobuhvatne ocjene kao takvi da ne bi mogli imati značajne učinke na okoliš“ “. ${ }^{42}$ još navesti presudu od 6. travnja 2000..$^{43}$ kojom je Sud osudio Francusku zbog toga što nije ispravno prenijela članak 6., stavak 3., Direktive 92/43/EEZ o staništima. Sud je utvrdio da „postojeća francuska pravila isključuju procjenu učinaka na područje određenih projekata zbog njihovog troška ili cilja, kršeći na taj način odredbe direktive“. Da bi utemeljio svoju tvrdnju o tome da članak 6. Direktive nije ispravno prenesen, sud smatra da je „dostatno istaknuti da ova odredba ne može ovlastiti državu članicu da donosi nacionalna pravila koja će općenito dovesti do izbjegavanja procjene učinka na području projekata prostornog planiranja zbog niskog iznosa predviđenih izdataka, odnosno u specifičnim područjima aktivnosti“.

Sve dovodi do mišljenja da će se ova sudska praksa po analogiji primjenjivati na članak 3., stavak 5. Direktive 2001/42/EZ. Države članice moći će usvojiti popis planova ili programa koji bi po službenoj dužnosti bili izuzeti od procjene okoliša iz direktive samo ako se za sve isključene projekte može, temeljem sveobuhvatne ocjene, smatrati da ne mogu imati značajne učinke na okoliš.

Članak 3., stavak 5. Direktive upućuje na dodatak II. kada se radi o kriterijima za određivanje mogućih značajnih učinaka na okoliš. Drugim riječima, formalne odluke, u skladu s pravilom, koje izuzimaju plan ili program od prethodne procjene okoliša morat cee se temeljiti na kriterijima iz dodatka II. Drugim riječima, u idealnim uvjetima, odluka o izuzeću trebala bi odgovarati ovim različitim kriterijima, odnosno barem onima koji se primjenjuju u danom slučaju, kako bi omogućili dostatno prepoznavanje razloga koji su naveli određeno tijelo vlasti da oslobodi određeni plan ili program od procjene okoliša. Komisija podsjeća da ovaj popis iz dodatka II. nije iscrpan.

Referirat ćemo se na praktični vodič Komisije za komentar na ove različite kriterije. Zadržat ćemo se samo na prvom kriteriju, odnosno „stupnju do kojeg plan ili program određuje okvir za druge projekte i aktivnosti bilo u odnosu na lokaciju, prirodu, veličinu i radne uvjete bilo po alociranju sredstava“, za koji Komisija smatra da što je plan ili program precizniji, to je procjena vjerojatnija.

41 Sud Europske unije, 2. ožujka 1996. Komisija protiv Belgije.

42 Sud Europske unije, 21. rujna 1999. Komisija protiv Irske.

43 Sud Europske unije, 6. travnja 2000. Komisija protiv Francuske. 
Podrazumijeva se da će se nadzor sukladnosti izuzeća od odredaba Direktive 2001/42/EZ temeljiti na analizi kriterija i načinu na kojih su ih nacionalna tijela vlasti ispunila. Što je obrazloženje preciznije i više utemeljeno, veće su šanse za postizanje sukladnosti.

\section{3. 4. Postupovne formalnosti u okviru korištenja mehanizma izuzeća}

Osim metode i kriterija koji omogućuju izuzeće plana ili programa od prethodne procjene, ključno je da direktiva nalaže postupovne formalnosti u okviru korištenja mehanizma izuzeća. Tako stavak 6. članka 3. nalaže da se traži mišljenje tijela nadležnih za okoliš iz članka 6., stavka 3. prije svake odluke koja bi mogla dovesti do izuzeća. Također, stavak 7. članka 3. nalaže državama članicama da poduzmu potrebne mjere kako bi zaključci doneseni temeljem stavka 5., uključujući razloge zbog kojih nije potrebno provesti procjenu okoliša, bili dostupni javnosti. Konkretno, to potvrđuje, kao što smo već istaknuli, obvezu nadležnih vlasti da formalno obrazlože razloge koji su ih doveli do toga da je neki plan ili program podložan procjeni okoliša, katkad zbog pojedinačnih slučajeva, a katkad zbog usvajanja popisa. Prema tome, to isključuje svaku implicitnu odluku. ${ }^{44}$

\section{4. Procjena okoliša u pravom smislu riječi}

Direktiva 2001/42/EZ u bitnome je postupovna jer nalaže poštovanje preciznih pravila o sadržaju procjene i o brojnim upravnim formalnostima koje se usmjeravaju na savjetovanje. Bez obzira na to radi li se o tijelima specijaliziranima za okoliš, stanovništvu ili drugoj državi čije područje bi moglo biti primatelj različitih okolišnih učinaka vezanih za urbanistički plan, direktiva nalaže da se zatraže njihova mišljenja što je ranije moguće. Također je potrebno da konačna odluka bude utemeljena ne samo na izvješću o učincima na okoliš, već i na rezultatima tih savjetovanja.

Sva ova pitanja zahtijevaju produbljenu analizu. ${ }^{45}$ Međutim, mi smo se odlučili zadržati na sadržaju procjene što ga nalaže direktiva i dodatak I., odnosno na pitanju alternativnih rješenja.

Direktiva 2001/42/EZ nalaže sastavljanje izvješća o okolišu u kojem se utvrđuju, opisuju i procjenjuju mogući učinci provođenja plana ili programa na okoliš kao i razumna alternativna rješenja, uzimajući u obzir ciljeve i zemljopisno područje primjene plana ili programa.

Dodatak I. direktive nabraja informacije koje mora sadržavati izvješće o učincima na okoliš, a posebno navodi „razmotrena alternativna rješenja“.

Članak 9., stavak 1. b) Direktive nalaže da izjava o okolišu koja na određeni način zaključuje postupak sažeto iznosi „,koji su razlozi za odabir plana ili programa, te kako je usvojen, s obzirom na ostala razmotrena razumna alternativna rješenja“,

44 Sud Europske unije, 14. lipnja 2001. Komisija protiv Belgije.

45 Vidi Haumont, Francis, Droti européen de l'aménagement du territoire et de l'urbanisme, Bruylant, Bruxelles, 2014., str. 124-154. 
što pokazuje trend u pravu okoliša koji se odnosi na pojavu načela zamjene ili nadomještanja.

Ovaj pristup nalazimo u Direktivi 92/43/EEZ o staništima, a članak 6., stavak 4. izričito navodi mogućnost odobravanja usvajanja urbanističkog plana ili izdavanje upravnog odobrenja zbog imperativnih razloga prevladavajućeg javnog interesa unatoč negativnim zaključcima odgovarajuće procjene.

Međutim, to pretpostavlja, osim usvajanja kompenzacijskih mjera, ${ }^{46} \mathrm{i}$ „nedostatak drugih pogodnih mogućnosti“ iz članka 6. Sud je Europske unije kaznio Portugal zbog odobrenja projekta autoceste koja prolazi područjem od posebne zaštite, a prema odgovarajućoj procjeni, sa značajnim učinkom na barem sedamnaest vrsta divljih ptica i na njihovo stanište, a da nije ispitana alternativna trasa koja ne bi predstavljala nikakav tehnički problem niti nerazumno povećanje troška, niti je zaključeno da je provođenja alternativnog projekta nemoguće. ${ }^{47}$

Nema sumnje da će Sud Europske unije jednom imati za razmatranje postupak o zakonitosti urbanističkog plana s obzirom na poštovanje Direktive 2001/42/EZ. U nedostatku preispitivanja drugih pogodnih mogućnosti ili obrazloženja koja su dovela do toga da ih nadležno tijelo javne vlasti ne prihvati, plan upotrebe zemlje mogao bi biti nezakonit i time opravdati svoje poništenje. Potrebno je razumno postupati tijekom postupka izrade i usvajanja tih planova.

\section{PRAĆENJE OKOLIŠA ${ }^{48}$}

Konvencija o procjeni utjecaja na okoliš preko državnih granica, donesena u Espou 25. veljače 1991., uvela je novost time što ima za cilj, ne samo obvezu povezivanja procjena okoliša država na koje se odnose učinci planirane aktivnosti preko granica države, a na području država potpisnica Konvencije, već za cilj ima i mogućnost produženja te povezanosti, u okviru a posteriori analize utjecaja na okoliš, aktivnosti koja je u međuvremenu odobrena i stvarno provedena.

Članak 7. Konvencije osigurava sljedeće: „1. Zainteresirane zemlje će na zahtjev jedne od njih odrediti da li i, ako da, u kojem opsegu treba izvršiti analizu nakon izrade projekta, vodeći računa o mogućem značajnom negativnom utjecaju aktivnosti preko granica države zbog čega je izvršena procjena utjecaja na okoliš u skladu s ovom Konvencijom. Svaka analiza provedena nakon izrade projekta treba posebno obuhvaćati nadzor aktivnosti i utvrđivanje svakog negativnog utjecaja preko granica države. Ovaj nadzor i utvrđivanje mogu se izvršiti s ciljem da se ostvare ciljevi navedeni u Prilogu V.

46 Vidi više o tome Haumont, Francis, Coût et emprise foncière des compensations environnementales, AJDA, 2007., str. 17-19.

47 Vidi Sud Europske unije, 26. listopada 2006., Komisija protiv Portugala.

48 Više o tome vidi u Marie-Pierre, Lanfranchi, Le suivi et l'évaluation pas les institutions communautaires in L'effectivitè du droit européen de l'environnement, Le Documentation Française, Paris, 2000., str. 85-97. 
2. Ako na temelju analize, izvršene nakon izrade projekta, zemlja porijekla ili pogođena zemlja imaju opravdane razloge za donošenje zaključka kako postoji značajan negativni utjecaj preko granica države ili ako su pronađeni čimbenici koji mogu izazvati takvu posljedicu, onda treba odmah obavijestiti drugu stranu. Zainteresirane zemlje se tada trebaju posavjetovati o neophodnim mjerama za smanjenje ili uklanjanje utjecaja.“”

Kijevski protokol od 21. svibnja $2003 .{ }^{49} \mathrm{o}$ strateškoj procjeni okoliša osigurava obvezu, a ne više samo mogućnost, praćenja učinaka planova i programa na okoliš koji su predmet procjene koju nalaže Protokol, a njegov članak 12. osigurava da:

„1. Svaka stranka prati značajne utjecaje provedbe planova i programa donesenih temeljem članka 11. na okoliš, uključujući i zdravlje, kako bi, između ostalog, u ranoj fazi utvrdila nepredviđene nepovoljne utjecaje i kako bi mogla poduzeti odgovarajuće mjere za njihovo otklanjanje.

2. Rezultati obavljenog praćenja stavljaju se na raspolaganje tijelima vlasti navedenimu članku 9. stavku 1. i javnosti u skladu s nacionalnim zakonodavstvom. “

Direktiva 2001/42/EZ potvrđuje ovaj doprinos i nalaže nastavak postupka procjene okoliša nakon donesene odluke. Radi se o obvezi zbog koje su države članice, u skladu s primjenom članka 10., stavka 1. Direktive, obvezne osigurati praćenje značajnih učinaka provođenja planova i programa na okoliš, kako bi se u ranoj fazi utvrdili nepredviđeni nepovoljni učinci i kako bi se bilo u mogućnosti poduzeti prikladne mjere otklanjanja.

Iz ove odredbe možemo zaključiti da države članice imaju dvije obveze. Prva je nesporna, one trebaju, nakon usvajanja plana ili programa, osigurati praćenje stvarnih značajnih učinaka plana ili programa na okoliš. Direktiva ne određuje što podrazumijeva pod „praćenjem“. Prema praktičnom vodiču, radi se o „praćenju promjena bitnih parametara u pogledu veličine, u vremenu i prostoru“.

Zanimljivo je imati na umu da direktiva, ne navodeći načine tog praćenja, nalaže da izvješće o učincima na okoliš sadržava opis predviđenih mjera praćenja. $\mathrm{K}$ tome, ove mjere praćenja sastavni su dio informacije za javnost i za tijela javne vlasti, s kojima se savjetovalo tijekom procjene, istovremeno s planom ili programom i izjavom o okolišu.

Osim toga, s obzirom na cilj ovog praćenja, u ovom slučaju radi se o brzom zahvatu kojim se ispravljaju nepredviđeni nepovoljni učinci utvrđeni u ranoj fazi. Praktični vodič je ipak pomalo kontradiktoran u odnosu na tekst Direktive po ovom pitanju. Zapravo, Komisija smatra da „ako praćenje može biti zadovoljavajuće uključeno u ciklus normalnog planiranja, možda neće biti potrebno osigurati odvojenu postupovnu etapu za njegovu provedbu. To bi se, na primjer, moglo podudarati s uobičajenom revizijom plana ili programa ovisno o učincima kojima su podvrgnuti i ovisno o vremenu između dvije revizije“. Ovaj komentar je iznijansiran, ali izgleda da će uobičajeni ritam revizije planova ili programa u

49 Ibid. 
velikoj većini slučajeva biti nespojiv s ranim značajem utvrđivanja nepredviđenih učinaka na okoliš.

Što se tiče nepredviđenih učinaka na okoliš, tj. ukoliko je procjena okoliša dobro sastavljena, ne bi se trebalo raditi o potpuno neočekivanim učincima, već više o nedostacima u ocjeni intenziteta učinaka koji su se očekivali kao i „nepredviđenih učinaka nastalih zbog promjene okolnosti koji djelomično ili potpuno kvare određene pretpostavke koje su formirane u okviru procjene okoliša."

Druga obveza odnosi se na posljedice utvrđivanja nepredviđenih negativnih učinaka tijekom tog praćenja. Ćlanak 10., stavak 1. osigurava da praćenje, u toj pretpostavci, omogućuje državama članicama „da su u mogućnosti poduzeti prikladne mjere otklanjanja“. Iako riječi koje se koriste nemaju željenu jasnoću, ipak nam se čini da sadržavaju temelj obveze za države koje moraju stvarno poduzeti mjere za otklanjanje negativnih učinaka plana ili programa.

I još jednom, Komisija iznijansirano prikazuje opseg ove odredbe na sljedeći način: „Ipak, direktiva nužno ne zahtijeva od država članica da mijenjaju plan ili program nakon praćenja. Ovaj postupak je u skladu s općim pristupom procjene okoliša koja olakšava jasnu odluku, ali koja ne stvara bitne „okolišne“ norme koje se primjenjuju na planove ili programe. Da zemlje članice, u okviru svog nacionalnog zakonodavstva, smatraju da su korektivne radnje bilo koja relevantna informacija dobivena zahvaljujući praćenju to bi, naravno, bilo korisno."

Ovo je određeni broj razmišljanja koja smo željeli izreći o temeljima i ciljevima europskog prava o procjeni okoliša urbanističkih dokumenata. Direktiva 2001/42/ EZ predstavlja važan potencijal u korist zaštite okoliša tako što nalaže istinsko promišljanje o učincima na okoliš koje bi urbanistički planovi mogli imati. Jasno je da su primjedbe u ovoj fazi tek prospektivne, te funkcioniraju na temelju analogija zbog toga što nema sporova.

Kao što smo spomenuli, ne postoji sudska praksa Suda Europske unije s obzirom na sukladnost prijenosa u pravom smislu riječi. A fortiori, nema sudske prakse Suda o primjeni in concreto prijenosa direktive. Također je izvjesno da nacionalni spor može na zanimljiv način razjasniti opseg Direktive 2001/42/EZ.

\section{ZAKLJUČNA RAZMATRANJA}

Zbog utjecaja na okoliš i životnih uvjeta stanovništva, procjena predstavlja veliki ulog, tim više jer je danas moguće odrediti trošak promjena koje su u tijeku, a vezane su za ljudsko djelovanje. Prema tome, neophodno je propitivati sami postupak te procjene. Poput studije utjecaja od 70-tih godina, radi li se o pokretanju procjene određenog projekta, instrumenta za planiranje, ili se radi o odgovaranju na izazove koje je čovječanstvo postavilo na lokalnom planu i na razini planeta u okviru završenog sustava, Zemlje? Stanje je takvo da je pravnik pozvan, barem kada se radi o mogućnosti materije, primjenjujući javnu politiku, odgovoriti na tako postavljene izazove. Ovdje se suočavamo s vremenom koje 
je potrebno za donošenje odluka (njihovu izradu i provedbu). Vrijeme hitnosti do kojeg dovode zabrinutosti oko onečišćenja, štete ili opasnosti, teško se može pomiriti s mjerenjem, a ponekad i sa zadržavanjem pravnog propisa. $\mathrm{K}$ tome, osim zbog prevencije, znanstvenici se obraćaju političarima i pravnicima kako bi uspostavili pravila čiju hitnost karakterizira djelovanje s kojim postoji više rizika od nepovratnosti. Osim toga, zahtjev koji se odnosi na održivi pristup nalaže integriranje obvezujućeg postupanja u sadašnjosti i potrebu budućih naraštaja čiju zastupljenost pravo još uvijek teško percipira. Ovo su samo neki od izazova s kojima se procjena okoliša mora suočiti. Ona nalaže shvaćanje ljudskog djelovanja u trajanju, a vrijeme se ovdje odnosi na prostor koji budućnost čini nepredvidivom. Prema tome, kontekst nam nalaže da ocjenjujemo izazove i suvislost te procjene, a posebice u pogledu njezina opsega, $\mathrm{tj}$. relevantnosti razvijene metode ili metoda. Integriranjem dvostrukog pristupa, prostora i vremena, čini se da moramo prijeći $\mathrm{s}$ vremena relativne procjene na vrijeme stvarne procjene sastavljene u kontekstu osnaživanja integriranog postupka. Direktiva o ,planovima i programima“ obilježava promjenu u zahtjevu koji se odnosi na razmatranje zabrinutosti po pitanju okoliša. Direktiva se čini kao da istražuje performativ (izričaj koji je sam po sebi čin djelovanja) u pogledu prevencije. Utemeljenost ove procjene nalazi se u direktivi iz 2001. godine koja zahtijeva ,skup zajedničkih postupovnih zahtjeva potrebnih za doprinos visokom stupnju zaštite okoliša“. Ovaj postupak izgleda kao pomoć pri odlučivanju, što je navedeno u 15. točki preambule Direktive koja kaže da je potrebno provoditi savjetovanja kako bi se doprinijelo „transparentnom donošenju odluka, a s ciljem osiguranja sveobuhvatnosti i pouzdanosti informacija koje se dostavljaju za procjenu“, a bit mehanizma temelji se na kapacitetu odgovornih sudionika koji će predvidjeti učinke planiranja u ranoj fazi „prije nego što se plan ili program usvoje ili upute u zakonodavni postupak“. Urbano širenje i negativni utjecaj na okoliš proizlaze zasigurno na barem jednako značajan način iz širenja ruralnih i periurbanih prostora koji nisu obuhvaćeni urbanističkim dokumentom. U konačnici, u praksi, svaki dokument se procjenjuje sam po sebi i za sebe, na temelju prethodno određenih značajki za svakog od njih. Neumoljivo se ispunjavaju ciljevi, iako nema učinkovite metode, nema nikakve usporedbe i, prema tome, nije provedena nikakva stvarna procjena.

Pravo urbanizma strukturirano je oko skupa temeljnih načela koja razvijaju integrirani pristup i trebali bi stvoriti relevantnu procjenu. Također, osim postizanja velike ravnoteže, multifunkcionalnosti prostora, urbanog obnavljanja i socijalne različitosti, izričita referenca za okoliš, „,upravljanje zemljištem na ekonomičan način“ ili „ekonomično i uravnoteženo korištenje prostora...", pozivaju na urbanu politiku koja se temelji na stvarnoj ocjeni utjecaja na zemljopisno područje razvoja ljudskih aktivnosti. Sudovi se pozivaju na nepoznavanje ekonomičnog korištenja kako bi sankcionirali plan korišstenja zemljišta (lokalni urbanistički plan). Konačno, mehanizam sam po sebi sadržava bitne slabosti. Predmetna Direktiva u svom 5. članku propisuje da se sastavlja izvješće o učincima na okoliš u kojem se „utvrđuju, opisuju i procjenjuju“, „razumna alternativna rješenja, uzimajući u obzir ciljeve i zemljopisno područje primjene plana i programa“. Postupak procjene dovodi 
do predstavljanja mjera za „nadoknađivanje negativnih učinaka“. Prema tome, kao i po pitanju studije utjecaja ili zaštite određenih prostora (npr. Mreža Natura 2000, prirodna područja), nadoknađivanje predstavlja poseban način provođenja planova i programa gdje planiranje ima prednost nad zaštitom okoliša. Na način na koji se razvija, procjena okoliša u pogledu urbanističkih dokumenata ima više „utilitaristički“" pristup i antropocentrični pristup prirodnim resursima, posebice tlu i vodi. Zahtjev u pogledu uzimanja u obzir prostora i vremena, globalnog i lokalnog, treba dovesti do osnaženog integriranja, neke vrste „,biosolidarnosti“ koja ide od lokalnog biotopa do biosfere. Različito ljudsko djelovanje na određenom zemljopisnom području dovodi do promjene lokalnih ekosustava i posljedično do utjecaja na biosferu, uz primjenu lokalnog urbanističkog planiranja. Nadilazeći ciljeve Direktive iz 2001., zahtjev u pogledu visoke razine zaštite okoliša nalaže da se utvrde novi zahtjevi koji su bliži stvarnoj procjeni.

Moramo utvrditi da je smanjenje bioraznolikosti, artificijalizacija, erozija tla, klimatske promjene kao onečišćenje resursa i njihovo prorjeđivanje rezultat korištenja zemljišta i prostora. Različita izvješća fondova Ujedinjenih naroda za stanovništvo, Međuvladin panel o klimatskim promjenama, Program Ujedinjenih naroda za okoliš, Europska agencija za okoliš (urbano širenje) pokazuju povezanost između uvjeta urbanog razvoja i negativnih učinaka na okoliš. U ime „održivijeg“ razvoja, brojne institucije pretjerano hvale razvoj. OECD također navodi da „održivost koja se često osmišljava na regionalnoj razini nije više samo obrana za pobornike zašite okoliša već i potreba za poduzeća i ključni čimbenik pri odlučivanju o osnivanju dizajnerskih, proizvodnih i upravljačkih subjekata“". OECD nadalje kaže da je „održivost okoliša potreba koja u prvi plan smješta nove prioritete zaštite okoliša i nove načine razmišljanja o tijekovima ljudi, robe i upravljanju otpadom“.

Ovladavanje urbanim razvojem postavlja zahtjeve u okviru integriranog i održivog postupka koji neophodno vodi do boljeg karakteriziranja procjene okoliša. Također se možemo referirati na procjenu koja se zahtijeva u okviru zaštite područja mreže Natura 2000. Naime, Sud Europske unije dobro određuje granice procjene u tijeku, iako nalaže koherentan pristup u pogledu zaštićenog područja. U presudi donesenoj 20. rujna 2007., Sud navodi: „Ova odredba osigurava da, pod pretpostavkom i unatoč negativnim zaključcima procjene izvršene u skladu s člankom 6., stavkom 3., prva rečenica ove direktive glasi da se plan ili program moraju provesti zbog imperativnih razloga prevladavajućeg javnog interesa, uključujući interese socijalne ili gospodarske prirode, te kada ne postoje druge pogodne mogućnosti, država članica poduzima sve potrebne kompenzacijske mjere kako bi osigurala zaštitu koherentnosti mreže Natura 2000“.

Kada govorimo o pravu, tada se radi o formaliziranju uvjeta za provedbu stvarne procjene. Ulozi su zajednički, metoda je još u povojima, a Direktiva iz 2001. otvorila je perspektivu. Humanističke znanosti trebaju razmotriti napretke drugih disciplina, u okviru interdisciplinarnog postupka, kako bi uistinu pomirile „zaštitu i valoriziranje okoliša, gospodarskog razvoja i društvenog napretka“. 
Možemo se referirati na pravne promjene do kojih je došlo u području klimatskih promjena: radovi znanstvenika doveli su do uvođenja mehanizama na dvije važne razine, globalnoj i lokalnoj. Protokol iz Kyota ${ }^{50}$ je također doveo do stvaranja još nedovršenog prava s obzirom na ulog, ali on dobro upućuje na ono što je moguće u pogledu metode. Radi se o nastajanju jedne vrste etike okoliša koja se „sastoji od studije pitanja i normativnih načela koji se odnose na interakciju čovjeka s njegovom prirodnom sredinom, u kontekstu u kojem se nalazi ta interakcija i njezine posljedice“.

Procjena ljudskih aktivnosti s obzirom na njihov neposredni ili globalni okoliš mora biti sastavni dio ove sheme, instrumenti za urbano planiranje predstavljaju ljudski kapacitet uz pomoć kojeg će ovladati ili neće s postrojenjima na danom području, ako se zna da svaki izbor određuje globalne utjecaje. Također, u svojoj procjeni koja se odnosi na artificijalizaciju zemljišta, Francuski institut za okoliš (FEN) navodi da artificijalizacija „uzrokuje gubitak prirodnih i poljoprivrednih resursa i obično nepovratnu nepropusnost zemljišta. “51

Međuvladin panel o klimatskim promjenama u svom izvješću iz 2007. godine navodi da se „ograničenja krčenja šuma i gubitak prirodnog staništa mogu primijeniti na društveno i gospodarski održiv način" ".52 Prema programu Ujedinjenih naroda za okoliš, ekološko stanje planeta je alarmantno. S obzirom na demografske promjene i kapacitet zemlje koji treba zadovoljiti potrebe, dokument otkriva da je 1950. svako ljudsko bice raspolagalo sa 5,15 ha dostupne površine, a 2005. godine ta se brojka svela na 2,02 ha.

Ako se pogledaju posljednja izvješća koja su znanstvenici objavili na međunarodnoj razini, postoji skup velikih problema koji su posljedica ljudskog djelovanja. Prema tome, procjena okoliša treba dovesti do istovremenog određivanja lokalnih i globalnih utjecaja kroz ocjenu ekosustava. Međutim, sama metoda ne bi bila dostatna da sustav procjene ne omogućuje provedbu analiza koje se oslanjaju na istovjetne parametre bez obzira na referentno zemljopisno područje i koje vode do usporednog pristupa.

Da bi se odgovorilo na izazove koje postavlja urbanizacija, posebice urbano širenje, nameće se jedan drugi put koji integrira okolišnu i društvenu zabrinutost. Paradoksi suvremenog svijeta otkrivaju osvješćivanje uloga i perspektiva koje, čini se, sadrži zakon o okolišu "Grenelle“. ${ }^{53}$ Međutim, istovremeno, nedavna izvješća, kao izvješće Attali, ${ }^{54}$ ne čini se da sadržavaju postupak održivosti. Kao što to naglašava autor, okoliš izgleda kao prepreka za koju se želimo uhvatiti kako bismo izbjegli integriranje ili kako bismo ukinuli rijetke nastale napretke kroz dotadašnju prizmu činjenica koje su sami znanstvenici opisali kao ozbiljne i nepovratne. Medijski učinak iznosi na vidjelo put koji još trebaju proći mislioci

\footnotetext{
50 http://narodne-novine.nn.hr/clanci/medunarodni/328925.html

51 http://urbanisme.u-pec.fr/

52 Haumont, Francis, Droit européen de l'aménagement du territoire et de l'urbanisme.

53 Ibid.

54 http://www.attali.com/
} 
prošlog vremena i oni koji brane rast koji se mjeri samo s obzirom na gospodarske i financijske interese.

Istinski se izazov pojavljuje pred urbanim politikama. Dok je načelo neovisnosti zakonodavstava dovelo do svođenja procjene na njezino područje, zahtjev za integriranim postupkom kao potreba da se ostvari održivi razvojni cilj za postojeće i buduće naraštaje poziva na nadilaženje ove usporavajuće vizije.

Provođenje procjene također dovodi do sličnih problema, neovisnost i sankcija nadzora su u središtu njezine relevantnosti. Okolišna etika, koja se zagovara u okviru UNESCO-a, otvara nekoliko perspektiva. Složenost problema koje stvara urbani razvoj, sinteza koja omogućuje teritorijalizaciju prava u tom okviru, uključivanje vremena u razmatranje okolišnih utjecaja pozivaju pravnika da pregleda strukturne elemente u tom području. Sve više znanstvenika ukazuje nam na to da se odluke moraju hitno donijeti. Osim medijskog agitiranja i pokazivanja, radi se o poduzimanju mjera vezanih za katastrofu koja se sve jasnije vidi, o mijenjanju pomalo paradoksalnog scenarija u kojem je žrtva također i počinitelj najavljene kataklizme, u svijetu u kojem ograničenost ostavlja sve manje mjesta za približnost. Jer, kao što naglašava izvješće IPCC-a, objavljeno u travnju 2007. i koje navodi ljudsku narav klimatskih promjena, „održivi razvoj može umanjiti ranjivost na klimatske promjene, ali klimatske promjene mogu otežati narodima njihov zanos da dostignu održivi razvoj“. Čini se da provođenje stvarne procjene okoliša, kao što se sugerira s ekološkim otiskom, vodi do redefiniranja ljudskih odnosa prema prostoru. Za pravnika, ova bitna pitanja koja se odnose na pristup zemljišnoj imovini, prisvajanje i katastarsko ovladavanje u središtu su ove perspektive.

In fine, javne politike moraju se razvijati u inovativnom okviru, stremeći prema novom upravljanju, $\mathrm{tj}$. sposobnosti da se odgovori na zahtjev ove međuovisnosti koja značajno opisuje ljudske odluke i djelovanja, bez obzira na razmatrano zemljopisno područje. Radi se o određivanju uvjeta interveniranja javnog djelovanja i o odgovornosti javnih vlasti s obzirom na životne uvjete i okoliš na planetu. 


\section{EUROPEAN VIEW OF ADMINISTRATIVE LEGAL PROTECTION OF THE ENVIRONMENT AND URBANISM}

Controlling urban development poses demands within the framework of integrated and sustainable procedure which inevitably leads to better characterisation of environmental assessment. In this sense, we will attempt to show how strongly and directly environmental assessment influences urban planning and the importance of Directive 2001/42/EZ. This article will limit itself to the area of directive application even though it will be dedicated to certain topics related to environmental assessment in a narrower sense and environmental monitoring as prescribed by the Directive. Ultimately, public policies must develop within an innovative framework, aiming for new management, that is, the ability to answer the demands of this interdependence which significantly describes human decisions and activity regardless of the geographical area. It is about determining the conditions for the intervention of public activity and the responsibility of public powers given the living conditions and environment on the planet.

Key words: administrative activity, urbanism, environmental protection, Directive 2001/42/EZ 